Portland State University

PDXScholar

7-9-1996

\title{
The Industrial Workers of the World and the Oregon Packing Company Strike of July 1913
}

Adam J. Hodges

Portland State University

Follow this and additional works at: https://pdxscholar.library.pdx.edu/open_access_etds

Part of the History Commons

Let us know how access to this document benefits you.

Recommended Citation

Hodges, Adam J., "The Industrial Workers of the World and the Oregon Packing Company Strike of July 1913" (1996). Dissertations and Theses. Paper 5290.

https://doi.org/10.15760/etd.7163

This Thesis is brought to you for free and open access. It has been accepted for inclusion in Dissertations and Theses by an authorized administrator of PDXScholar. Please contact us if we can make this document more accessible: pdxscholar@pdx.edu. 


\section{THESIS APPROVAL}

The abstract and thesis of Adam J. Hodges for the Master of Arts in History were presented July 9, 1996, and accepted by the thesis committee and the department.

COMMITTEEAPPROVALS:

DEPARTMENT APPROVAL:

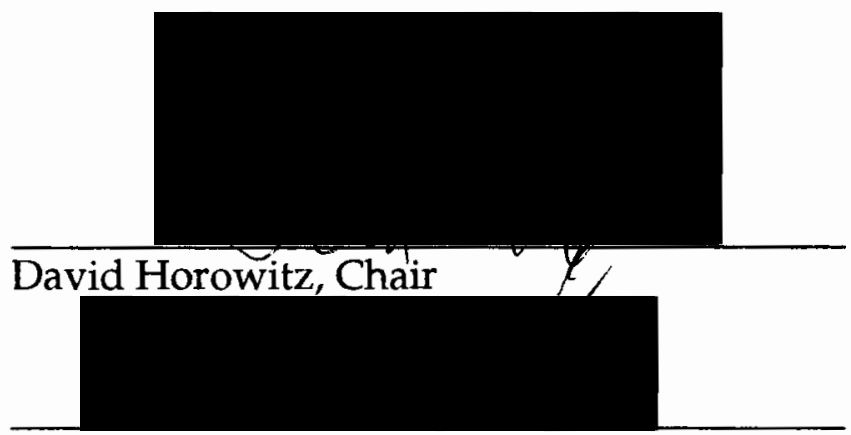

Franklin West

Graig Wolner

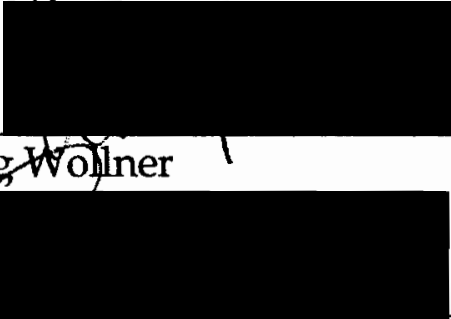

Robert Liebman

Rep. of the Office of Graduate Studies

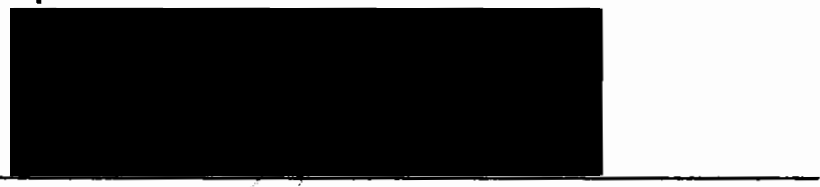

David Johnson, Chair

Department of History

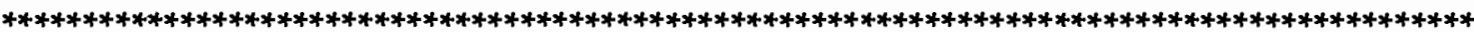

ACCEPTED FOR PORTLAND STATE UNIVERSITY BY THE LIBRARY

by

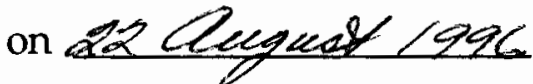




\begin{abstract}
An abstract of the thesis of Adam J. Hodges for the Master of Arts in History presented July 9, 1996.
\end{abstract}

Title: The Industrial Workers of the World and the Oregon Packing Company Strike of July 1913

This study builds upon the notion of a Wobbly 'sensibility' established by Salvatore Salerno and relates it to John Townsend's analysis of conflict between that group's adherents and western Progressives. The latter scholar, by concentrating on middle-class economic anxiety, failed to deal with the virtual unanimity of opposition to the IWW in western towns. Salerno's assertion that a 'sensibility' within the IWW was more binding than ideology raises the possibility that individuals and organizations of varying beliefs could be similarly united within a single cultural sphere with a directed purpose. Such an analysis can apply to factions of Progressivism and radical labor alike.

The first chapter begins with a brief account of the historical context, origins, and organizational history of the IWW. This second section discusses the internal dynamic of the IWW, particularly the relationship between the leadership and rank-and-file. The third section briefly explicates the purpose of the thesis. The second chapter recounts important episodes of IWW activity that occurred on the West Coast concurrently with the strike in order to set the regional context of the conflict.

The third chapter begins with a section discussing the development of 
Progressivism and urbanization in a national context and emphasizes cultural conflict. The second section is a brief survey of Progressive era Portland, Oregon. The third and fourth sections discuss the cultural repercussions of women entering industrial life on a mass scale. The chapter concludes with a brief demographic survey of cannery women.

The fourth chapter is a chronological narrative of the strike, and is followed by a concluding fifth chapter of analysis. The first section suggests a Progressive 'sensibility' arrayed specifically against radical labor, while the next section discusses a radical 'sensibility' hostile to varying aspects of the cultural norms of Progressivism. The final section asserts the importance of analysis of cultural values, above even notions of class, in addition to economic analysis in order to obtain a more useful synthesis of Wobbly conflict than now exists. 
THE INDUSTRIAL WORKERS OF THE WORLD AND

THE OREGON PACKING COMPANY STRIKE

OF JULY 1913

by

ADAM J. HODGES

A thesis submitted in partial fulfillment of the requirements for the degree of

\section{MASTER OF ARTS \\ in \\ HISTORY}

Portland State University

1996 


\section{Preface}

The Oregon Packing Company, a fruit cannery located near the industrialized riverfront of Portland, Oregon's working-class East Side, battled a walkout by a significant number of its predominantly female workforce during the peak of the canning season in 1913. The strike holds little significance for students of institutional labor history, for it was unsuccessful both in achieving its demands and unionizing the protestors. In fact, the wane of the season prevented these women from even returning to the jobs they had fought to improve. Why, then, is the strike worthy of close study?

The action can serve as a rich tapestry displaying the cultural transformation that emerged from the dramatic shifts in industrial relations during the Progressive era. Many such strikes have been overlooked because labor historians have so often placed economic analysis above cultural. Perhaps because the strike was doomed to failure, conducted within a seasonal industry and outside of accepted norms of labor relations, the vigorous nature of the protest is so noteworthy. Before the strike itself is chronicled in the fourth chapter, a good deal of contextual understanding will be required in order to read fully into its signifcance and to understand the concluding chapter that follows. At issue is the nature of the cultural cohesiveness within both the strike coalition and the Progressivist consensus that represented community opposition to the methods of the protest. Therein lies much of the substance of the tensions between the two.

The IWW quickly became the focus of public attention during the conflict although they were merely one segment of a coalition. To complicate 
matters, scholarly work on the Wobblies has quite often reinforced such simplistic notions. In order to rectify these distorted perceptions, a thorough examination of the historical context and historiography of the Wobblies will serve as the focus of the first chapter. Special attention will be paid to the internal dynamic of the IWW in order to clarify the roles of culture and ideology within the union. The second chapter recounts four incidents on the West Coast during the summer of 1913 in which the IWW participated. This section will serve to contextualize the Portland conflict and raise some of the major issues concerning the union's participation in economic actions.

Although it will become clear that the IWW was both internally divided and capable of participating in coalitions, Progressives viewed the union as monolithic. The shrill public outrage against the Wobblies, goaded by a relentlessly antagonistic local press, demands an understanding of the context and development of Progressivism both nationally and in Portland. Particular attention is reserved in this third chapter for the intersection of economic and cultural tensions within Progressivism. Confusion over the appropriate place for women within the context of public protest and industrial relations will be a substantial focus. 


\section{Table of Contents}

Chapter 1

Chapter 2

West Coast IWW Activity

Summer 1913

Chapter 3

Progressivism \& Industrial Life

39

Chapter 4

Oregon Packing Company Strike

69

Conclusion

Cultural Sources of the Conflict

96 
Chapter I

Historical Context of the IWW 
The fifty women who marched out of the Oregon Packing Company on the morning of June 27, 1913 to protest low wages were part of a dramatic economic shift that transformed virtually every aspect of American social and cultural life in less than half a century. Although the U.S. population increased at the dramatic rate of $132 \%$ between 1870 and 1910 , the number of laborers moving into industrial jobs quadrupled. Alan Trachtenberg has noted that "wage labor emerged, unequivocally, as the definitive working class experience," with the ind ustrial work force claiming more than a third of the nation's population by 1900 . As the economy was transformed by incorporation and industrial growth, workers sought to further their collective interests. ${ }^{1}$

The Knights of Labor was the first significant attempt by 'producers' (which, at this point, included small businessmen) to prevent the permanency of the wage system. Established in 1869 by a tailor, the Knights thrived in the 1870s and 1880s, before massive levels of immigration and economic growth erased the possibility of establishing a cooperative commonwealth built on traditional American ideals. In the 1890s, a substantial portion of the Knights lost interest in the seemingly hopeless ideal of transforming the economy and began to expound a pragmatic philosophy based on acceptance of corporate capitalism and an emphasis on immediate gains for workers. This constituency, composed mainly of native white males who worked in skilled crafts, filtered into the American

1David Montgomery, The Fall of the House of Labor: The Workplace, the State, and American Labor Activism, 1865-1925 (Paris: Cambridge University Press, 1987) 54; Alan Trachtenberg, The Incorporation of America: Culture \& Society in the Gilded Age (New York: Hill \& Wang, 1982) 87. 
Federation of Labor (AFL) and left the Knights in terminal decline. The rapid growth of AFL membership after its inception in 1886 and the disappearance of the Knights dramatically increased the exclusivity of labor organization. The Knights had been fairly open to all races, ethnicities, laboring occupations, and both genders. The AFL, however, served a small homogeneous group of elite craft workers. Yet, the dramatic growth of unskilled industrial occupations, and the mass entry of immigrants and women into those jobs, left the vast majority of workers unrepresented in an economy that was leaving them increasingly impoverished. In the late 1880 s, $45 \%$ of ind ustrial workers hovered just above the poverty line while $40 \%$ were below that level.2

To a substantial number of these excluded individuals, the concept of syndicalism held out hope for a collectivist society governed by workers. Syndicalists intended that after mass organization workers would elect councils, by industry, that would coordinate the government and economy. The idea was radical and transformative, differing from the reform of the Knights in that it looked to a completely new culture based on working-class collectivism rather than one of Jeffersonian independent producer values. Syndicalism was not American, it was becoming international and had its roots in radical western European socialist philosophy. It also differed hugely with the approach of the pragmatic AFL, for syndicalism was openly antagonistic to compromise approaches with capitalism and refuted the validity of contracts made within the wage

2Trachtenberg, 94-96, 90. 
system. Syndicalists espoused the active ruination of the economy through sabotage on the job, civil disobedience, and eventually, when the bodies to take over the state and economy were in place, a general strike of all workers to topple the current regime. The first mass expression of this radical philosophy in the United States was the Industrial Workers of the World (IWW), formed in 1905.3

The IWW was inspired by the precedent of two recently created labor organizations: the American Railway Union (ARU) and the Western Federation of Miners (WFM), both founded in 1893. The ARU and WFM were based upon the principle that unions should be organized along industrial, rather than craft, lines. This approach allowed the organization of those excluded from skilled crafts on a significant scale for the first time, and prevented the division of workers within industries into craft fiefdoms, which weakened solidarity. The WFM had already made two previous attempts to form a multi-industry union, with the Western Labor Union (WLU) and the American Labor Union (ALU). To prevent yet another failure, the WFM began seeking the cooperation of like-minded individuals and organizations to form a broad-based, radical alternative to the AFL.4

The IWW was the fruit of this outreach, drawing in (among others) Daniel DeLeon of the Socialist Labor Party (SLP) and Eugene Debs, leader

${ }^{3}$ Discussion of syndicalism from Salvatore Salerno, Red November, Black November: Culture and Community in the Ind ustrial Workers of the World (Albany: SUNY Press, 1989).

${ }^{4}$ Discussion of origins and organizational history of IWW from Melvyn Dubofsky, We Shall Be All: A History of the Industrial Workers of the World (Urbana: University of Illinois Press, 1988). 
of the Socialist Party and founder of the ARU. Meeting in Chicago, its founding convention brought together an eclectic group of union organizers and radical politicos who formulated the blueprint for a working-class utopia. Yet, strong tensions between proponents of political and economic action resulted in the repudiation of socialist political activity as a means to achieving a syndicalist state. The wrangling that led to this decision resulted in the departure of the WFM, whose leaders quickly despaired of the new organization. The remaining Wobbly leadership insisted on the plausibility of supplanting the state with an industrial democracy in which all power would be derived from workers and expressed through their delegates. Economic, not political, agitation and organization would be the means of achieving a new working-class regime through a syndicalist state. 5

Although the IWW was opposed nationally by the AFL, its most powerful opponents prior to World War I were regional. Provincial newspapers, commercial associations, and politicians railed against the radical philosophy and methods of the Wobblies wherever they became active. Clearly the national government did not find the Wobblies a threat to American institutions, for constant pleas for federal intervention fell upon deaf ears. During the War, however, the IWW aroused the wrath of the state by threatening production levels in two key industries: timber and mining. Open opposition to the war and fermentation of labor unrest instigated a Bureau of Investigation sweep of IWW offices in 1918-19, and trials for hundreds of leaders. In the Pacific Northwest timber industry, the Army 
actually took over operations and formed a new, compulsory union.

Having lost most of their assets and leadership, the Wobblies were crushed organizationally and never reemerged in the postwar period. Despite its inability to survive World War I and the 'red scare' of 1919-20, the IWW left a strong legacy of labor insurgence. 6

During their most active decade (1908-18), Wobblies led dramatic and highly publicized industrial strikes in the Northeast; the Paterson, New Jersey and Lawrence, Massachusetts textile walkouts were the most notable. Yet, the union's greatest success came in organizing itinerant agricultural and extractive workers in the Middle and Far West. The IWW became a portable home for homeless western laborers, a cultural fellowship and a means to redress grievances that focused on forests, fields, and mines to which the mass media and middle-class reformers would never venture. Strongly imbued with the gruff and iconoclastic sensibility of the WFM, the union would come to mold itself both organizationally and culturally to this western hobo contingent. 7

Many aspects of the IWW remain unclear, however, due to dissension among its chroniclers over the course of the century. Early accounts of the

6Ibid.

7libid. 
union evoked the image of a demon. John Graham Brooks condemned the movement in a 1913 study that criticized the perceived drift of European and American socialism into the rascality of syndicalism. Brooks viewed syndicalists as irreverent upstarts, and an insult to well-behaved traditional socialists. He ridiculed the Wobbly tactic of organizing "the man in the gutter," and "working children and the blacks." Given this constituency, he claimed, the notion of all wealth originating in labor was "so exhaustively silly" and "so childish as to excite suspicion of its motive." Yet, Brooks believed that the "used and ignorant masses should also have their own representatives. All attempts to prevent this are now too late." His solution focused on eliciting more gentlemanly behavior from capitalists and granting (as vaguely as possible) "genuine rep resentation in ... management" to workers, stressing that ignoring the laboring masses and public opinion would have serious consequences. Moderate and trustworthy individuals were to cease sitting on the sidelines and negotiate solutions to labormanagement tensions that would steal the IWW's thunder. 8

In contrast to Brooks, a handful of more liberal intellectuals such as Paul Brissenden were excited about the new ideas expounded by the Wobblies although they eschewed its radical methods. Brissenden published a study of the Wobblies in 1919, in which he asserted that "the most important item in the affirmative part of the I.W.W. program" was the "demand that some of our democracy ... be extended from political into

8John Graham Brooks, American Syndicalism: The I.W.W. (New York: Macmillan, 1913) $73-75,82,241$. 
economic life." Brissenden saw little difference between the ultimate goal of liberal Progressivism and IWW ideology. He suggested that "the Wobblies would have 'capitalism' ... supplanted by economic democracy just as political despotism has been supplanted by political democracy in nearly all civilized states." Writing during World War I, when the globalization of liberal Progressivism still seemed plausible, Brissenden was prescient of the economic democratization that would begin in earnest with the New Deal. However, although the goals of the IWW impressed him, the organization itself did not. He suggested that "even though capitalism may be ripe for replacement, the I.W.W. are a long way from being fit to replace it. The Wobblies are grotesquely unprepared for responsibility." Brissenden eschewed IWW advocacy of sabotage, demands for complete control of ind ustry, and neglect of consumer welfare. As a liberal economist and Progressive, Brissenden found the syndicalism of the Wobblies to be both irresponsible and as autocratic as the system it sought to replace. 9

The collapse of the Wobblies, already complete by the time Brissenden's study appeared, caused interest in the union to erode significantly until the social history movement and a growing contingent of sympathetic historians of the left emerged in the 1960s. The first major study of the IWW in this period, that of Philip Foner, an avowed Marxist-Leninist, appeared in 1965. For Foner, syndicalism was not the type of reckless socialism that it had been for Brooks and Brissenden. Referring to previous

9Paul F. Brissenden, The I.W.W.: A Study of American Syndicalism (New York: Russell \& Russell, 1957) xix-xxi. 
studies of the union, Foner claimed that "no one would realize from these accounts that the I.W.W. made valuable contributions in the campaign to organize the unorganized." He framed the Wobblies as both bold, displaying "heroic militancy," and irresponsible, falling prey to "serious flaws in its ideology" that would have, in any case, prevented eventual triumph. Following on the heels of Joyce Kornbluh's 1964 anthology of IWW primary sources, Foner's account helped define the Wobblies as misunderstood heroes, culpable only for their lack of coherent ideology. He lamented their destruction by "an alliance of big business and government" that simply used World War I as an excuse to vanquish the union. Those that clashed with the IWW were part of a systemic defense of capitalism lashing out at a dangerous foe. 10

Melvyn Dubofsky's survey of the Wobblies, the most thorough yet written, appeared in 1969. Although more restrained than Foner in his praise for IWW heroism, Dubofsky concluded the volume with regrets that the role of labor radicals in the modern western world had been only to serve as midwives of the welfare state. Like Foner, Dubofsky assumed that the Wobblies presented a viable threat to the smooth functioning of the American economy and forced compromise from frightened capitalists. "Employers who were threatened by the IWW paid greater attention to labor relations," he asserted. Yet, Dubofsky's own meticulous research belied such statements. In order to elevate the Wobblies to heroic status, however

10Philip S. Foner, History of the Labor Movement in the United States, Volume IV: The Industrial Workers of the World, 1905-1917 (New York: International Publishers, 1965) 9, 558; Joyce L. Kornbluh, ed., Rebel Voices: An I.W.W. Anthology (Ann Arbor: University of Michigan Press, 1964); Foner, 558. 
flawed, historians had to portray the union as potent.11

The myth of Wobbly effectiveness had been savaged by Robert Tyler in 1967 in his account of IWW activity in the Pacific Northwest. Yet, his work failed to significantly influence contemporary scholarship, evinced by the continuity between Foner and Dubofsky. Tyler saw IWW agitation as frequently violent, yet pointless. Its success in the region sprang from forces of rapid upheaval, both economic and demographic. He found in the Wobblies a pioneer spirit: individualist, rugged, and nonconformist. This perspective received little notice from more doctrinaire contemporaries, for it would have placed the IWW within a regional tradition, rather than a new and radical mold. In addition, Tyler's skepticism concerning the Wobblies was too extreme, his disdain for their 'free speech fights' too strong, to shift the course of IWW historiography singlehandedly. 12

Joseph Conlin's brief 1969 study set about to correct some common myths concerning the Wobblies. Yet in doing so, he overemphasized their normality. Conlin maintained that the 'free speech fights' were solely oriented towards organization, and that the IWW had faith in the court system and were adept at compromise with municipal authorities. Although a valuable restraint upon further romanticization by subsequent historians, Conlin's study mistakenly removed the IWW's uniqueness: he failed to deal with the Wobblies as a significant and nontraditional social

11Dubofsky, 483-484.

12Robert L. Tyler, Rebels of the Woods: The I.W.W. in the Pacific Northwest (Eugene: University of Oregon Books, 1967) Chapter 1. 
movement and cultural community. 13

Despite challenges from Tyler and Conlin, the work of Foner and Dubofsky seems to have led many recent scholars to focus on systemic interpretations of the brutalities that IWW members suffered. In a 1986 journal article, Dennis Hoffman and Vincent Webb employed a narrowly Marxist thesis in order to explicate police responses to the Wobblies in Portland and Seattle. Their analysis can be broken down into three areas: local political uses of police, the criminalization of the surplus labor force, and the buttressing of the existing social order. The authors asserted that during the economic crisis of 1913-14, "the authorities in Seattle and Portland 'criminalized' the surplus labor force by charging the unemployed with vagrancy and treating them as though they were real criminals." They traced such repression to the fact that overproduction in the lumber industry had created a large pool of men who were trained to cut lumber and drifted in and out of work. This situation was ideal for lumber company owners, who could easily find trained workers when they were needed and could pay them paltry wages because the demand for work was so high. Hoffman and Webb went on to assert that although this brand of economy cost the cities in the short run due to welfare dole payments, in the long run, they received "higher tax revenues" and "easier access to loans" from increasing wealth in the logging industry. Portraying the two cities as microcosms of a larger two-class systemic struggle, Hoffman and Webb

13Joseph Robert Conlin, Bread and Roses Too: Studies of the Wobblies (Westport, CT: Greenwood Publishing, 1969) 74-76. 
assume that "the 'Wobblies' ... presented a militant threat to industrial capitalism."14

John Townsend's dissertation on the cultural sources of anti-Wobbly violence, published in the same year as Hoffman and Webb's article, provided a much needed counterweight to the rigid ideological analysis often associated with scholarship on the Wobblies. Townsend argued that the western battles between IWW activists and municipal authorities were products of the growing marginalization of both social groups. As business activity became nationally centralized in large corporations, the AFL grew also, creating the beginnings of what would later become a societal balance between two powerful conflicting bureaucracies. The individuals who were being squeezed out by this process were radical labor leaders, laborers in unmechanized ind ustries, and small business interests. In the West, the first group attempted to organize the second, and both met strong resistance from the third. Townsend asserted that "although Progressive reforms attempted to curb disorder, many citizens were apprehensive." The source of their anxiety was the emerging shift of power to far-removed corporate and labor bureaucracies. He found that the local businesspeople who encouraged brutal anti-IWW vigilantism were Progressives, and "these activities were not incompatible." Wobblies themselves were also struggling against an increasingly marginal role. Townsend suggested that "they were basically outsiders, excluded from the emerging forums that

14Dennis E. Hoffman and Vincent J. Webb, "Police Response to Labor Radicalism in Portland and Seattle" Oregon Historical Quarterly 87 (Winter 1986) 356-357. 
began to regulate labor conflict."15

The historiography of the IWW indicates that scholars have had difficulty interpreting the relationship between the revolutionary rhetoric of the organization and the character and behavior of its transient rank-and-file. Contemporary accounts found the leadership to be irresponsibly radical and its following to be empty vessels for outrageous ideas concerning the societal debt to labor. Brooks and Brissenden both focused on an irresponsible leadership goading simple laborers toward self-destructive (and societally abhorrent) behavior. Their work would not be significantly challenged until a new generation of social historians in the 1960s prompted a reevaluation of the relationship between leaders and led.

Philip Foner played a major role in this reevaluation, finding a commonality of leadership ignored by previous historians. The Wobbly principle that official leaders were servants of their members, and all workers should lead, precipitated a lack of respect for the union's officials and a great deal of accompanying mistrust and dissension. Individual leaders suffered constant antagonism. Foner cited the case of Fred Heslewood, lambasted for owning his own home. The leadership as a whole 
also received constant threats to its authority. "Almost every single issue of the Industrial Worker," Foner wrote, "contained at least one article or resolution demanding decentralization of the national administration." In keeping with the ideals of the social history movement and with Foner's Marxism, the rank-and-file was framed as politicized and empowered. Although Foner's evidence evoked a vivid picture of struggle within the ranks, his Marxist tenets did not allow him to reach the conclusions his research suggested. "The Wobblies shelved their disagreements over leadership," he stated, "and presented a united front to the class enemy." Foner projected the alienation of IWW leaders from existing social and institutional norms upon the rank-and-file, and assumed a strong philosophical connection between leaders' and 'followers.'16

Building upon Foner's idealistic and ideologically motivated study, Dubofsky asserted that the union's confrontations "were instigated primarily to overcome resistance to IWW organizing tactics and also to demonstrate that America's dispossessed could, through direct action, challenge established authority." Yet, Conlin's work seemed to have offered a more complex picture of IWW activity. Because organizers could not recruit on the job (which would have necessitated penetrating countless miles of forest and farmland), they operated in the towns where transient workers came to weather the off-season. Soap box speaking was a valuable device for attracting attention to the Wobblies from itinerant workers. But the loss of this privilege affected organizers, not workers. Rank-and-file 
involvement in the 'free speech fights' seems to have been triggered by pentup anger over living and working conditions rather than the loss of civil liberties. To agree with Dubofsky's assumption that "the IWW and its members did challenge the law and endure violence and imprisonment to win free speech" requires a leap of faith that there indeed was a politically motivated and shared agenda among the transient workers of the brutal western wilderness who came and went with the seasons. 17

Like Foner, Dubofsky seemed to suggest that the motives shared by the leadership of the IWW could be ascribed to the rank-and-file. His description of the factors driving union membership appeared highly idealistic and generalized, and perhaps offered more insight into the composition of the leadership than of their followers:

Feeling impotent and alienated, these men harbored deep grievances against the essential institutions of the ruling classes: police, government and church. Hence, Wobblies ... exhibited a high suscep tibility to unrest and to radical movements aimed at destroying the established social order.

Wobblies tended to live a life that was quite isolated from societal institutions and almost certainly did not have the understanding of them that their more urban and industrial counterparts did. Socialist blueprints for a new society would have been of interest to a minority of the membership who were familiar with literature on the subject, but this minority was surely insubstantial in the forests, fields, and mining camps of the West. 18

17Dubofsky, 173-175.

18Dubofsky, 150; Tyler, 26. 
However, the IWW leadership did have a great deal of shared experience with its constituency. After the last of the socialist politicos had been purged at the 1908 national convention, the remainder was composed partially of dedicated ind ustrial unionists who had themselves been laborers (often migrants in western mining or agriculture) and European immigrants well-versed in socialist scholarship and French syndicalism. The latter group intended to use the IWW to organize the millions of immigrants caught up in industrialization and exerted a powerful influence on propaganda. However, the native western faction of the leadership was much more successful in recruitment. Although it was being pulled in two directions, toward both the western wilderness and the eastern cities, the IWW's membership demographics indicate that it was indeed a western non-ind ustrially oriented organization. However, because it contained leaders attracted to a variety of constituencies, it had the appearance of a national organization in both its organizing activity and propaganda. 19

Both elements of the leadership went through a personal evolution that led to revolutionary socialism, but under different circumstances. It was this disparity of experience that led them to agree on theory but disagree on direction. William Haywood and William Trautmann, both of whom served as Secretary-Treasurer of the IWW, were quite representative of the western and eastern leadership factions respectively. Haywood was a Utah born hard-rock miner, who after twelve years experience became a WFM official in Idaho and then a Socialist Party activist. He was self-taught,

${ }^{19}$ Characteristics of leadership and demographics of rank-and-file from Dubofsky. 
of rough-hewn intellect, and was primarily an organizer and administrator, not a theorist. William Trautmann was an immigrant with experience in the socialist labor movements of Russia and Germany, who worked as an organizer and editor for the Brewery Workers Union in Massachusetts. He helped found the IWW, which made him its first Secretary-Treasurer, and was remembered as an inept administrator but an active theorist and agitator. 20

Both men obtained their hatred of 'bourgeois' institutions through socialist political involvement and union organizing experience. However, their goals were markedly different. Trautmann hoped to organize steel and textiles in the Northeast, while Haywood looked to lumber and mining in the West. Although an active political socialist, Haywood remained suspicious of intellectuals and certainly represented the rank-and-file more closely than did Trautmann. Dubofsky's assertions regarding IWW alienation certainly apply to both Haywood and Trautmann. However, the two men developed their antagonism to 'bourgeois' institutions through sophisticated political activity. Dubofsky submitted that after the IWW was effectively crushed by the Justice Department in 1918, it became "a radical fellowship and not a functioning labor organization." However, the idea of 'fellowship' expressed by Dubofsky as characteristic of the postwar Wobblies seems actually to have been its great strength throughout its earlier and more vital period. 21

20Biographical information from Dubofsky, 238-239 (Haywood), 108 (Trautmann). 21Dubofsky, 108, 238-239, 474. 
While Foner and Dubofsky projected the radical alienation of IWW leaders on followers, Tyler dismissed possibilities of politicization among typical Wobbly recruits. He was immediately skeptical of their revolutionary fervor:

Probably most transient workers became Wobblies at one time or another during their careers, either enthusiastically or because of coercive 'box-car recruiting.' But the dedicated Wobbly, the member remaining loyal even during the periods of calm between free-speech fights or wild cat strikes, was an uncommon creature even among the hoboes.

Tyler maintained that the hobo culture of the West was antithetical to the stability that organization required. He concluded that easily transferable union cards and low dues turned the IWW into a social fellowship which functioned primarily to quell the loneliness of migratory existence. 22

Tyler acknowledged that the IWW served to legitimate, even exalt, working-class culture in general and western hobo culture in particular through shared legends and art forms. He described a typical Wobbly cartoon "glorifying a sturdy workman who belabored serpents of capitalism with a formidable club labeled 'I.W.W.' from behind a shield labeled 'organization' or 'solidarity.'" The shared songs and martyrs of the movement provided an almost portable community. Indeed, on this point, there seems to have been consensus between the leaders and the led. The language of IWW propaganda incessantly reinforced the moral superiority of a productive laboring life. Tyler demonstrated how cartoons and songs were an accessible way to communicate values and established shared ideas 
between the top and bottom of the union.23

Tyler argued that episodes of open battle against local authorities or bosses were the real substance of the Wobblies and emerged "only because of its failure as a labor union." Time and again Wobblies would help direct an ind ustrial strike, leaving thousands of new members in its wake, only to have these tangible gains evaporate over mere months through poor administration. In the West, where the bulk of the membership could be found, efforts to maintain stable and efficient union locals were frustrated by a transient constituency. Thus, organizationally, the links between the union administration and the rank-and-file were tenuous indeed. Yet, Tyler ignored the many instances when the leadership won tangible gains by concentrating its forces upon a single location and issue.24

Although the central leadership of the IWW was never successful at establishing competent regional and local administrations, it succeeded in channeling the anger of workers who could not practically be organized into traditional union structures. The leaders of the IWW adapted their organizational structure and tactics to fit their unconventional constituency, inevitably making the union itself highly unconventional. Tyler's synthesis emphasized the informal nature of the IWW as an organization but ignored the necessity for unconventional tactics in job circumstances not amenable to traditional union formats. As both a cultural community and a functioning labor organization, the IWW espoused diverse goals and practiced varied

${ }^{23}$ Tyler, 11.

24Tyler, 53-54. 
methods to achieve them. .25

Salvatore Salerno's 1989 study of Wobbly ideology and culture made significant strides in understanding the internal dynamic of the union. Salerno's cultural synthesis of the Wobblies as a social movement was highly instructive and helped to resolve contentious issues concerning the relationship between leaders and led. Because he employed a macro thesis, Salerno's definitions can be universally applied to the union without regard to industry or region. This vast perspective led to his development of the concept of "a sensibility" holding sway within the organization rather "than a doctrine or formal ideology." This sensibility was responsible for giving "passage to the social networks that defined its community." Creation of a sensibility, "as opposed to ideological affiliation," changed the very nature of the possibilities of the union. Wobblies were able to "create a common cultural sphere whereby the various ethnic groups could be united on the basis of shared sentiment." Salerno insisted that the IWW had a cultural, rather than institutional, basis. Consequently, cultural influences, as much as economic and political, were to be recognized.26

The focus of the present study is to build upon the notion of an IWW

25Dubofsky, 173-175.

26Salerno, Chapter 6. 
'sensibility' established by Salerno and relate it to Townsend's analysis of conflict between western Wobblies and Progressives. Townsend's synthesis explained why two increasingly marginal groups struggled openly and bitterly against each other while often tolerating the very forces that marginalized them. Yet his work provided only a partial explanation of the conflicts he addressed. By concentrating on middle-class economic anxiety, he failed to deal with the virtual unanimity of Wobbly condemnation in western towns. Citizens from all walks of life proved themselves capable of language like that of Judge Davis of Minot, North Dakota who exclaimed: "We'll drive the God Damned Sons of Bitches into the river and drown them. We'1l starve them. We'1l kill every damned man of them or drive them together with the Socialists from the city." 27

Salerno suggested that a 'sensibility' among Wobblies could prove more bonding than ideology. This assertion raises the possibility that a shared 'sensibility' could unite individuals and organizations of varying beliefs within a single cultural sphere with a directed purpose. Such an analysis can apply to factions of Progressivism and radical labor alike. Despite their demonization by the contemporary press and subsequent glorification by recent historians, the Wobblies were capable of submerging themselves within coalitions, playing a much more minor role than they would inevitably be credited with. In keeping with this thinking, the relationship between the rank-and-file and the leadership within radical labor coalitions could be rather fluid, under constant negotiation. Similarly, 
expansive anti-Wobbly coalitions raise the possibility of equally fluid, yet quite extensive, inter-class cooperation under the cultural umbrella of Progressivism.

The Oregon Packing Company strike of July 1913, set in Portland, Oregon, will be the context in which this study will explicate the aforementioned concepts. Although not as violent as the most famous 'free speech fights,' the conflict was fought through bitter words and sometimes dramatic confrontations between a newly formed Progressive municipal administration, desperate to prove itself capable of preserving order, and a coalition of striking women, local radical socialists, and Wobblies. An explication of the cultural values of both factions will provide answers to the questions raised by the work of Townsend and Salerno, and will be the focus of the conclusion of this study. This thesis is intended to emphasize the importance of analysis of shared cultural values in the study of economic conflict. 


\section{Chapter II}

West Coast IWW Activity

Summer 1913 
On June 25, 1913, a mob of 600 Marshfield, Oregon residents marched IWW activists W.J. Edgeworth and Wesley Everett to the sea and sent them eight miles from the town, instructing them "to keep going and never return." Immediately following this deportation, two Wobblies who had just arrived in Marshfield received similar treatment. Before casting them off in a second boat, "a committee of citizens who had escorted them ... Made them get down on their bended knees and kiss the American flag." The event was marked by deeply felt emotion. The crowd sang patriotic songs, and the small coastal town virtually shut down for the parade to the sea. Edgeworth had been the Secretary of the IWW Local, and the seizure of his belongings after his deportation yielded the union roster. Local businessmen kept the roll records "for the clearing out of other IWW." A local newspaper, The Times, was very admiring, asserting that "Coos Bay has cause today to be proud of the character of its citizenship," and describing the deportation parade as "one of the most remarkable demonstrations ever witnessed in any American city." It was the culmination of its fourteen month editorial tirade against the Wobblies.1

The IWW became active in the Coos County area of Oregon in 1911, although it had established a presence in Portland as early as 1907. A sparsely populated coastal area economically reliant upon timber, Coos was home to many a 'bindlestiff' ripe for IWW organization. The Times, typically, saw all Wobblies as alien, refusing to admit that some of the region's resident lumber workers responded positively to the union's appeals. In May 1913, matters 
came to a head when the IWW called an area-wide lumber camp strike to demand higher wages and an eight-hour day. William Robbins, an historian of the region, asserted that "newspaper editorials and commercial organizations on the bay had created an atmosphere of hatred against the IWW" by the middle of the month, the scheduled time to strike. Local businessmen were sworn in as special law enforcement officers, and braced for a fight. No disturbances actually occurred. However, Wobblies forced one logging camp to shut down and spurred partial walkouts in others. The action proved futile, but it enraged the propagandized citizenry and helped precipitate the mob scene that occurred the following month. 2

The populace of Coos had traditionally tolerated socialism. The Coos Bay Harbor stated in 1906 that "socialists number some of our best and foremost citizens." Yet the commercial and press campaign waged against the Wobblies during 1911-13 changed this praise to suspicion. Although Eugene Debs polled almost twice as many votes as the Democratic candidate in Coos during the 1904 presidential election, evincing significant leftist sentiment in the region, tolerance waned after the Wobbly deportation. However, socialists who used restrained language and espoused traditional modes of industrial relations remained in favor. Anti-IWW propaganda in the region had drawn a clear line between working-class advocates who threatened violence and sabotage, and those that spoke of cooperation. A radical socialist centered in Marshfield, C.B. Ellis, wrote to Tom Burns, an associate in Portland, in late May 1913 describing

${ }^{2}$ Robbins, 141; Lumbermen in the Pacific Northwest were often referred to as 'bindlestiffs,' in reference to the practice of carrying a bundle of bedding from one camp to another in search of work; Robbins, 141. 
the treatment that his beliefs had precipitated. He claimed that his "life and liberty are in hourly danger." He wrote of the disorganization of local socialists and the cowing of local business into a staunch anti-socialist stance by the Smith-Powers Company, local lumber baron. Ellis drew a clear distinction between himself and "the bourgeois element in the party here," who "could not be relied upon in a crisis." He described Marshfield as a "little stagnant community thoroughly permeated with petty local patriotism."3

One of his few local allies was Bandon socialist and chiropracter Dr. Bailey Kay Leach, publisher of the radical journal Justice. Two weeks after the Wobbly deportation in Marshfield, a mob drove Leach from Bandon. F.K. Chapburne, "a Bandon Socialist and an esteemed citizen," stressed that the local party branch "looks with disfavor upon the intemperate and insulting language used by Leach in his paper." Association with the language used by the IWW was now enough to transform any individual into a pariah. However, Leach did not remain undefended. Governor Oswald West was outraged by the editor's deportation, and threatened local officials with removal for failing to discipline the mob. West blamed "the radical element of the IWW's and leading businessmen of Bandon" for the mob disturbances that spurred the deportations. He assigned the state Attorney General to the case, declaring that the Sheriff of Coos County should be removed.4

The Governor cast blame for creation of the mob upon timber baron $\mathrm{Al}$ Powers of the Smith-Powers Lumber Company, declaring that "he has proved

${ }^{3}$ Robbins, 140; C.B. Ellis, letter to Tom Burns, May 30, 1913, Tom Burns Papers, Oregon Historical Society, Portland, Oregon.

4Oregonian, August 9, 1913, p. ; August 3, 1913, p. 6. 
himself an enemy of society and an outlaw." Powers had risen from the position of water boy in Michigan lumber country at age thirteen to become a wealthy power broker on the southern Oregon coast who American Lumberman described as "the personification of energy." He was a classic example of the 'self-made man' ethos that westerners still clung to despite its receding possibilities. West postured himself carefully, condemning the IWW as well as Leach himself, but stressing the importance of the rule of law. He also railed against the hypocrisy of the industrial elite, claiming that Powers "would be the first to appeal to this office" if a mob attacked his mills, yet he "resorts to mob rule when it suits his convenience." Here clearly was an issue where the Governor could position himself as a law-and-order populist. 5

The Governor blamed "weak-kneed officials" for the development of IWW activity, and stressed the necessity of strict enforcement of the law and the handing down of maximum legal penalties. The four Wobblies forcefully deported from Marshfield finally received notice as a component of West's case. Three days after the Governor referred the case to his Attorney General, the Oregonian reported that news of an investigation was "music to the ears of Sheriff W.W. Gage" of Coos Bay. The accused official "only feared that the Chief Executive would not carry out his promise in the matter." The Sheriff claimed that Dr. Leach "refused protection" and also "declined the good offices of Socialist friends." The doctor paid for his own boat fare, which the Sheriff took as evidence that he "was willing to take his departure immediately." Yet, that his departure was involuntary, and real protection non-existent, is clear.

5 Oregonian, August 3, 1913, p. 6; Robbins, 33-34; Oregonian, August 3, 1913, p. 6. 
When Leach's attorney wired the Sheriff that the doctor wished to return to Bandon from Myrtle Point immediately, but required protection, the Sheriff "found no warrant of law obliging him to act as an escort to any person." The case quickly died, however. Robbins cites election year politics as responsible for "the attorney general's whitewashing of the issue." A grand jury was appointed, but failed to reach a decision. No further action was taken. 6

On July 13, 1913, while tension emerging from the IWW led Oregon Packing Company strike gripped Portland, the Oregonian informed its readers in a dramatic front-page story that the "IWW LEAD MOVE TO DISRUPT ARMY." Correspondent Will MacRae reported from Fort Stevens, near Astoria, that "the first prying of the lid to the gigantic IWW plot to disorganize and demoralize the Army and Navy" was taking place. MacRae insisted that:

the higher ups have selected a class of men, made dangerous by a little education, and have urged them to join the Army and Navy so they could spread the doctrine of discontent and opposition when the bayonets of the government are directed against rioters and sabotage.

His findings were based upon "days of close investigation" and "heart-to-heart talks" with both socialists and non-socialists connected to the investigations at the fort.7

The mysterious murder of a Private Crawford at the fort had been

60regonian, August 3, 1913, p. 6; August 6, 1913, p. 5; Robbins, 142.

7 Oregonian, July 13, 1913, p. 1. 
quickly followed by the desertion of a Sergeant Leary after it had become clear that he had been responsible for pamphleting the saloons of nearby Hammond with socialist literature. A shack in the woods behind the fort was then discovered, a sort of socialist reading room for interested soldiers. These events caused a whirl of investigation, including attempts to link the active socialist chapter in Astoria, and even the Pacific headquarters of the Army at the Presidio in San Francisco, to these events. The alleged immediate discovery of a Secret Service agent relocated to the fort from San Francisco, as well as Leary's supposed tip off concerning his imminent arrest, led to fears that the IWW had access to secret cables at both the Presidio and Fort Stevens. 8

Scapegoats emerged immediately. Private Coffman, an allegedly obstreperous member of the Astoria socialists, and a soldier at the fort, emerged as an example, and was tried for making seditious remarks. A man MacRae referred to as Lawton, "a constructive and not a destructive Socialist," who quit the Astoria group in protest after Coffman was admitted, objected to his "violent remarks" and advocacy of "free love." While Lawton was described as holding a "thoroughly philosophical view of Socialism," a later article implied that Coffman held completely untenable opinions concerning the compatibility of socialism and anarchy. As in the Coos County press, an understood demarcation between responsible and reckless socialism is clear. Certainly, the Wobblies helped lend definition, and raise alarm over, the latter type. Four other soldiers were also brought up on charges, including a Private Johnson, accused of stealing a pint flask of Dennite, described as the most powerful and 
secret explosive material in existence. The IWW, in this context, emerged as an organization truly feared as a potent revolutionary force. Yet, the absence of significant federal intervention prior to World War I denigrates the assertion that the Wobblies truly were a threat to either the nation's defense or industrial production capacity. 9

While the Fort Stevens trials and the accusations against Coos Bay authorities began to grind through the courts, a truly explosive event in Wheatland, California heightened already strong anti-Wobbly sentiment on the Pacific coast. On August 3, 1913, a peaceful protest meeting of 400 striking hoppickers on the Durst ranch erupted into violence when a posse, composed of sheriff, district attorney, constable, and deputies, arrived at the ranch and waded into the crowd to arrest their leader. A warning shot was fired to calm the crowd, but had the opposite effect. A melee erupted, leaving District Attorney Manwell, a deputy sheriff, and two hoppickers dead after perhaps twenty shots had been fired. 10

The origins of this tragic protest remain unclear. Typically, authorities immediately shouldered the Wobblies with full blame. In his official report to

9 Oregonian, July 13, 1913, p. 1; July 25, 1913, p. 12; July 20, 1913, p. 7.

10Contemporary narrative found in Oregonian, August 4, 1913, p. 1. Historical narrative found in Philip S. Foner, History of the Labor Movement of the United States, Volume IV: The Industrial Workers of the World, $1905-1917$ (New York: International Publishers, 1965) 258-280. 
the Governor in fulfillment of his duties as Executive Secretary for the State Immigration and Housing Commission of California, Carleton Parker completed a contemporary factual and statistical record of this event that would be impossible for a historian to surpass. Parker compiled the affidavits of 97 witnesses, 57 of whom he presented as "perfectly reliable." Yet, his interpretations of the evidence presented, and his judgment of what comprises reliability, seem highly suspect. Vincent DiGirolamo has found that Parker was contemptuous of male migrant workers, particularly foreigners. After a 1913-14 study of 222 California migrant males revealed to him that over three-quarters were unmarried and a substantial majority planned to drift from place to place indefinitely, he deemed this class morally inferior. Another report conducted by Parker, in conjunction with the Stanford University Department of Education, tested 200 migrant laborers and deemed a quarter of them to be "feebleminded." 11

In Parker's opinion, foreign workers on the Durst ranch "had, as a rule, unclean personal and camp habits, exposed themselves at the pumps in washing, and were indecently careless in the presence of women and children." Although, as a solid Progressive, Parker deplored the camp conditions, he never speculated if perhaps these alleged unclean and indecent habits were unavoidable given the circumstances. One witness, cited by DiGirolamo, asserted that "the moral conditions of these hop-fields are notoriously lax," perhaps owing to Durst's failure to provide tents or segregate families from

11Carleton H. Parker, The Casual Laborer and Other Essays (New York: Harcourt, Brace and Howe, 1920) 176; Vincent DiGirolamo, "The Women of Wheatland: Female Consciousness and the 1913 Wheatland Hop Strike" Labor History 34 (Spring 1993) 236-255. 
single migrants. The provision of only five wells and two hydrants for 2,738 individuals, often emptied before the day had barely begun, surely contributed to the state of affairs. There were also only between eight and eleven toilets, "one-tenth of the army minimum," which quickly became too foul to use, and resulted in "women humiliating themselves before passing men," and children in "unspeakably filthy condition." Sickness became rampant, and the heat unbearable, to workers denied even free water by Durst. 12

Of the 2,738 individuals in the camp, Parker's study found 1,438 to be foreigners. He also asserted that of the total number there were 700 or 800 hoboes who were "in every sense potential I.W.W. strikers," at least 400 who knew the "philosophy of the I.W.W. and could also sing some of its songs," and 100 card-holding IWW members. Thirty of the latter group, he claimed, organized the camp in merely three days. Placing a small number of Wobblies as sole instigators and organizers of the protest seems simplistic given the limited time frame and large number of migrants, half of whom had varying degrees of difficulty speaking English and had over two dozen disparate native tongues. Although this causal paradigm has become a commonplace assumption in historical analysis of the event, DiGirolamo has used photographs indicative of social patterns at the ranch to conclude that the camp was not "just heterogenous hop pickers, but a community." Cletus Daniel also points out that "in their initial responses to news of the Wheatland riot, Wobbly spokesmen insisted that none of those named as strike leaders was an IWW

12Parker, 174; DiGirolamo, 240; Parker, 182; DiGirolamo, 241. 
cardholder."13

Authorities responded with a state-wide manhunt for the Wobbly leaders they felt to be responsible for the deaths of the district attorney and deputy sheriff. The search resulted in the trial of four men in January 1914, and ended with the conviction of two of them. It was fairly typical in contemporary disturbances involving any alleged Wobblies for authorities to overshadow any other possible motivations for group action. DiGirolamo's innovative study has credited consciousness and social patterns among women in the Durst camp with the ease with which a network of solidarity was quickly constructed. Little evidence of a direct Wobbly conspiracy exists. Daniel found that California IWW locals in 1913 had virtually given up on successfully organizing migrant workers until "the Pacific Coast was further industrialized." Even after Wheatland had provided the impetus for unionizing the fields, Wobbly leaders in the state continued to emphasize political agitation over organization. 14

Yet, while Daniel has seen already meager efforts to unionize migratory workers in decline, the contemporary view was markedly different. In his official report of the event, Parker stated that it was now common for hoboes in the state to know IWW songs by heart and to sing them whenever they found themselves in groups. But, he continued, "this was not so three years ago." Although Parker clearly understood that Wheatland was not a Wobbly plot fomented from the outside by the leadership, he saw the spread of IWW doctrine creating a "small army" of roaming migrants who would start trouble

13Parker, 189; DiGirolamo, 245; Cletus E. Daniel, "In Defense of the Wheatland Wobblies: A Critical Analysis of the IWW in California" Labor History 19 (Fall 1978) 493.

14Daniel, 492-493. 
wherever they could. He reported that "the I.W.W. is teaching a method of direct action which will give this class expression in violent flare-ups" while leaving no lasting organization. Parker seems to have been extrapolating such conclusions from the violent 'free speech fights' at Fresno and San Diego, both quite recent, and the dearth of any constructive activity in the wake of Wheatland. The leadership's revolutionary rhetoric and emphasis on political action pushed suspicions onto the rank-and-file of fomenting violence for its own sake. 15

The evidence that survives of the riot at the Durst ranch contradicts the validity of such characterizations. Although Parker called IWW propaganda in California a "criminal conspiracy," it seems that camp conditions on the Durst Ranch were a much stronger impetus to action than inflammatory doctrines. Three days hardly seems adequate for a handful of men to indoctrinate hundreds of individuals, half of whom were not native English speakers. And the alleged Wobbly organizers were preaching passive resistance, not the direct action through sabotage and violence condemned by Parker. Richard 'Blackie' Ford, a former Wobbly and the workers' spokesman on the ranch, held up a sick baby to the peaceful crowd and exclaimed "it's for the kids that we're doing this!" No mention of revolution. Clearly, the abysmal conditions at the camp, and Durst's intransigence, triggered a campaign of passive resistance formed by a community with common grievances and goals that were both simple and immediate. Wobbly propaganda and the past experience of IWW veterans perhaps increased the pace of events, but it seems unlikely that Ford

15Parker, 190-191. 
and the other leaders had come to the ranch merely to agitate. Their tactics, negotiation in good faith and passive resistance, were clearly at odds with the Wobbly tradition. 16

Demonization of the IWW completely out of proportion to its activities similarly thrived in Seattle. The trouble had begun when a newly elected progressive Democrat Mayor, George F. Cotterill, replaced Hiram Gill in 1912. Gill had been recalled by an outraged citizenry for his complicity in Seattle's thriving vice industry. Cotterill's administration focused on restoring civic pride in municipal government through elimination of vice and official corruption. In replacing Gill, however, Cotterill earned a potent enemy, Colonel Alden J. Blethen. The Colonel (his title of dubious origin) "worshipped the military with a school boy's simplicity" and exhibited a chauvinistic brand of patriotism. Yet, he had been a firm backer of the corrupt Gill administration and ran a sensationalist newspaper, the Seattle Times, which held the truth in little regard and was widely criticized for conjuring conspiracies. 17

The events of 1912 framed an antagonistic relationship that would come to focus on tolerance of free speech, and that of socialists in particular. Cotterill's Progressivist instincts drove him to balance public demand for order

16Parker, 193; DiGirolamo, 236.

17Robert L. Tyler, Rebels of the Woods: The I.W.W. in the Pacific Northwest (Eugene: University of Oregon Books, 1967) 44-45. 
with concerns that legality not be flouted by civic authorities. Sensitive to public outrage against corruption and private use of public power, Cotterill intended to be careful in his use of the police force. Blethen, conversely, chafed at the idea of rights for socialists. In 1912, Leonard Olsson, a Wobbly from Tacoma, lost his citizenship in a federal court that found he had committed fraud during the naturalization process. His transgression was found to be the maintenance of loyalty to the United States, which was deemed in direct contradiction with his later discovered Wobbly membership. Such treatment was not unique. Judge William Galloway, presiding over the federal circuit centered in the Albany area of Oregon, announced in late July, 1913, that all applicants for citizenship in his jurisdiction would have to pass an IWW litmus test. In support of his decision, Galloway told the press that "membership in that organization is almost prima facie evidence that a man is unfit for citizenship." After a long campaign by socialists and Wobblies, Olsson regained his citizenship through appeal in February 1913. Although this was hardly a setback for anti-Wobbly legal repression, Blethen was indignant over the mayor's tolerance of public protests in support of Olsson. Particularly galling was official permission for a May Day parade in 1912, in which the red flag and the American flag were carried side by side, precipitating riot. Cotterill had actually created this situation as a compromise, mediating between socialist factions and citizen groups. 18

The issue of the red flag was an emotional one, and Blethen was far from isolated in his opinions. Local socialists attempted to stage a satirical play

18Tyler, 44-45; Oregonian, July 31, 1913, p. 7; Tyler 45. 
unfavorable to both Colonel Blethen and veterans titled "The Colonel and his Friends" in the Moore Theater in late July, 1913. Spanish-American War veterans threatened to pack the theater and riot at the first hint of insult to the American flag. A seeming continuation of the May Day controversy of the previous year, the Mayor again stated that he had no authority to stop the play, but that he would again negotiate a settlement. Socialists agreed to avoid statements in the production indicating that Blethen controlled the local veterans, and to abstain from insulting use of the flag. They further promised to refrain from recreating the May Day riot of the previous year. This time, Cotterill's compromise maintained the peace. The play remained a point of contention, however, and the manager of the Tacoma Theater refused it a showing in his town.19

The antagonism over the proper extent of First Amendment rights for Seattle socialists that reemerged concurrently with the production of "The Colonel and his Friends," and large IWW street meetings, was brought on by the most serious anti-leftist violence the city had yet seen. On July 18,1913 , the Potlatch Days festival hosted by Seattle erupted in violence. Large crowds of sailors and soldiers had been given leave to attend the festival, planned as a summer tourist attraction by local businessmen. The trouble seems to have emerged from two vague and exaggerated reports in the Seattle Times. The first concerned the contents of a speech made by Secretary of the Navy Josephus Daniels to Seattle's exclusive Rainier Club on the evening of July 17. A routine patriotic speech that Daniels had used time and again during his national tour

19 Oregonian, July 26, 1913, p. 4; July 29, 1913, p. 5. 
on behalf of the new Wilson administration, was manipulated by the Times to appear as a repudiation of Mayor Cotterill's supposed tolerance of local socialists and their denigration of the national flag. That this was Daniels' intent hardly seems likely, for not only was Cotterill, like President Wilson, a progressive Democrat, but he had served as the Secretary's host and sat behind him on the stage during his speech at the club. Despite the fact that the Secretary later claimed that "what I said last night concerning patriotism had no reference to any situation in Seattle," the front-page article written by M.M. Mattison in Blethen's paper seems to have been persuasive. 20

The second article, a brief scuffle reported by the Times in the same issue, set off a riotous mob on a parade of destruction. In the wake of the paper's vague description of the event, a rumor spread that several servicemen had been injured after interfering with an IWW street meeting. This rumor, after "smoke has cleared away," was entirely discredited by the Seattle Daily Sun, as ardent a supporter of Cotterill as an opponent of Blethen. The paper stated that the truth of the supposed initial altercation between enlisted men and Wobblies, backed by the affidavits of witnesses and the official reports of military officers, was completely at odds with the Times' account. The confrontation that instigated the rumors did not actually involve the IWW at all. Annie Miller, a women's rights advocate, was antagonized by an intoxicated soldier who later returned with similarly inebriated companions and removed her speaking stand, staging a mock meeting of their own. The crowd laughed, until Mrs. Miller attempted to retake her stand and the soldier 20Tyler, 45-46; Oregonian, July 19, 1913, p. 4. 
who instigated the whole disturbance raised his hand to strike her. A "welldressed man, with a diamond ring," stepped out of the crowd to defend her. The man's appearance precludes him from being a Wobbly, and Mrs. Miller was similarly unconnected to the union. 21

The brawl that followed quickly became distorted to scapegoat the IWW, and rioting ensued. As the rumor spread, crowds of servicemen and sympathetic civilians formed to take revenge. One party "waving United States flags ... swooped down on the cart newsstand of Millard Price," who sold socialist literature, and smashed it to pieces. The group then came across a recently vacated Wobbly headquarters, and proceeded to move on to the nearest socialist hall. Upon finding it, they smashed in the plate glass window, tore signs off and nailed flags to the edifice of the building, and were only molested by police after attempting to drag books and furniture out into the street. Previously, the "policemen smiled complacently upon the wreckers." The crowd, en route to further destructive activity, was waylaid by a police captain with reinforcements who ordered the group to disperse. The Oregonian reported shouts of: "your Mayor won't do anything to protect the flag, so we are saving your city" and "go and get Mayor Cotterill" emanating from the mob. This account lends strong credence to the notion that the Times report of Daniels' speech was responsible for the violent reaction to the rumor of a clash between servicemen and Wobblies. The mob reformed further north in the city and a new group emerged in the south. The former group finished the destruction of the socialist headquarters begun earlier, while the latter group 
finally found and sacked the IWW hall. Several more socialist meeting places were set upon, and a Salvation Army office was also mistakenly destroyed in the frenzy. When a mob of one thousand passed the Rainier Club, its members reportedly lined up and saluted before moving on. 22

Cotterill responded to the crisis by obtaining an injunction to shut down the Seattle Times, and closed the city's taverns until the conclusion of the festivities. Blethen quickly overturned the injunction, and blasted the Mayor in his July 20 issue. Cotterill was forced to respond with a lengthy defense of his conduct in the Seattle Daily Sun. Both Cotterill and U.S Representative J.W. Bryan tried to win reparations for those whose property had been destroyed. When Cotterill presented demands to the City Council, however, the police force, which had been quite passive during the incident, denied Seattle's liability. Bryan asked Congress to pay for the damage, citing the blameworthiness of the U.S. Navy, but was declared out of order for presenting an appropriation as a resolution. Wobblies and socialists even sent a joint delegate to the Capitol to present their case, to no avail. Immediately after the riots, the Seattle IWW held a series of large outdoor meetings downtown, which resulted in an injunction sought by local businessmen on the grounds that the commercial district was being thoroughly disrupted. After briefly flouting the court order, Wobblies desisted before a full-blown 'free speech fight' could emerge.23

\footnotetext{
22 Oregonian, July 19, 1913, p. 1, 4.

23Tyler, 46-47; Congressional Record, 2903-2904; Tyler, 47-48.
} 
Chapter III

Progressivism \& Industrial Life 
Labor relations and industrial reform in early twentieth century America operated within the context of a Progressive world-view, which emerged as "the expression of a profound cultural crisis caused by the rapid urbanization and industrialization of the nation during the nineteenth century." The hope that the United States "would be saved from the terror of history just because it was agricultural" could no longer survive as an article of civic faith. By the late nineteenth century, a movement of various coalitions emerged with disparate ideologies, but a remarkably consistent focus on the importance of economic self-determination for communities and a quest for social "purity and unity." Desires for economic independence were primarily expressed through antimonopolism, while the social purity movement often expressed itself through a rejuvenated Protestantism. As Daniel Rodgers has suggested, Progressive social reform did not have a common agenda but shared three separate "languages of discontent" containing universal symbols. Rodgers has pointed to the importance of strains of antimonopolism, "a rhetoric of social cohesion" to replace emphasis on the individual, and "the language of social efficiency." He has emphasized that these languages were rife with contradictions, yet helped to focus ferment on "arbitrary, unregulated individual power."1

Antimonopolism had long held a place in American cultural discourse prior to the 1890s, dating back at least to Andrew Jackson dismantling the Second Bank of the United States in 1832 in an attempt to further democratize

1David W. Noble, The Progressive Mind, 1890-1917 (Minneapolis: Alpha Editions, 1981) 1; Robert H. Wiebe, The Search for Order, $1877-1920$ (New York: Hill and Wang, 1967) 52, 56; Daniel T. Rodgers, "In Search of Progressivism" Revierus in American History 10 (December 1982) 123. 
access to credit and disperse power more evenly throughout the banking industry. The perceived popularity of the 'Bank War' was perhaps its most important driving force within the Jackson administration. Rodgers has asserted that antimonopolism in the Progressive era had a new and important facet; it had "gained the acceptance of insiders." While populist discontent with the centralization of power in the economy can be traced from Jackson to agrarian populism, the end of the century brought a recognizance by the urban middle-classes that government intervention was required. Rodgers proposed three potential explanations for this development: the "sudden ... ascendancy of finance capitalism," the rapid growth of monopolistic urban services networks, and a growing middle-class desire for the excitement provided by muckraking journalism. ${ }^{2}$

The source of the grievances of rural middle-class entrepreneurs is much more clear. Wiebe has noted that "two bursts of railroad construction" following 1879 and 1885 saw more track laid than at any time in the nation's history. The main lines between cities had already been built; this was largely 'feeder' track to join previously isolated rural communities to main railroad lines. Regional competition among individual merchants did not increase as result of the expansion of 'feeder' track, for "integrated wholesale houses" became the standard means of purchasing goods for retail sale by the $1880 \mathrm{~s}$. Consumers now had less flexible credit with local merchants, for these entrepreneurs in turn were reliant on large and impersonal providers of bulk 
goods. Previously, the business world had been relationship-based for these individuals, both as merchants and consumers. Now, far-off financiers and administrators determined many of the financial aspects of intra-communal relationships. Perceived theft of economic autonomy would draw the entrepreneurial middle-classes, urban and rural, into the previously agrarian populist chorus for federal regulation of the business world. The passage of the Interstate Commerce Act in 1887 and the Sherman Anti-Trust Act in 1890 are evidence of the vocalization of such demands. 3

What Rodgers referred to as "the language of social bonds" and Wiebe as "a preoccupation with purity and unity" was an outgrowth of the dramatic shifts in American social life brought about by the nationalization of the economy and the centralization of distribution networks. New cultural definitions were required for what appeared to be a new kind of society, and a public demand to participate in the humanization of these transformations arose. Rodgers pointed out that the rhetoric of unity often took on opposing guises, citing Theodore Roosevelt's focus on "the social whole" and Jane Addams' focus on immediately interactive social units such as family and community. Common ground on the issue of social unity was reached, Wiebe asserted, through Protestantism.4

The research of Charles Howard Hopkins into the transformation of American Protestant theology in the late nineteenth century indicates that the religious community was coming to terms with modernity. Hopkins has noted

3 Wiebe, 47-49, 52-54.

4Rodgers, 125; Wiebe, 63. 
that progressive theologians accepted Darwinian theory in the 1890s, leading to a belief in "the divine presence in nature and in human society." These individuals determined that the alienation of the masses from religion had emerged from a false separation of the sacred and the secular. "Good works have been subordinated to sanctification," lamented Professor Charles Briggs of the Union Theological Seminary, "rendering [Protestantism] unresponsive to the needs of modern life." Briggs noted that this policy had been responsible not only for forcing humanitarian work outside the churches, but had even occasionally garnered the opposition of religious leaders to such activity. In 1899, Professor Graham Taylor of the Chicago Theological Seminary delivered an address to the International Congregational Council in Boston on the modern mission of the church. Taylor stressed the need for a "science of Christian society" and the imperative of launching social movements from within the church. This new 'social gospel' provided a massive social network and ideological impetus to reform activity in American life. 5

Rodgers' third strand of discourse in Progressivism was "the rhetoric of social efficiency." This more academic mode of idea sharing put "social disorder into words and remedies free of the embarrassing pieties and philosophical conundrums that hovered around the competing language of social bonds." It was the language of an emerging class of technocrats that sought to rationalize society on a secular scientific basis, yet it successfully integrated itself with many of the goals of the 'social gospel.' The urban

5 Charles Howard Hopkins, The Rise of the Social Gospel in American Protestantism, 1865-1915 (New Haven: Yale University Press, 1940) 123, 136-138. 
political rebirth promised by the commission form of government began to take hold in 1909, while advocates of scientific management proposed the elimination of waste and class conflict in American industry in 1910.6

Frederick W. Taylor's theories captured the public imagination as a salve to the alienation of factory life and the perceived growth of class warfare. Taylor emphasized that workers were to be treated as individuals in order to assess their capabilities, introducing "individualism into the factory." $\mathrm{He}$ simultaneously limited the prerogatives of capitalists by attacking "the cult of personality in management" and attempting to establish the primacy of "methods" over "particular men." Taylor's theories seemed to contain the notion of brotherhood extant in the 'social gospel,' for although workers would lose what little control they maintained over work practices, foremen would lose the right to hire and fire them arbitrarily. It was a vision of factory communities, that although not quite viable in practice, provided a popular image of peaceful and consumer oriented industry. 7

All three of Rodgers's languages of Progressivism converged upon the most dramatic manifestation of the age, the city. During the period between 1870 and 1920, rural residents and foreign immigrants poured into towns at a stunning rate, transforming them into cities often over only brief periods. The urban population expanded from ten to fifty-four million over this half-century. Between 1870 and 1920, the number of cities of 50,000 and greater grew almost six-fold. As early as 1890 , practically all urban centers destined to achieve

6Rodgers, 126-127.

7Samuel Haber, Efficiency and Uplift: Scientific Management in the Progressive Era, 1890-1920 (Chicago: University of Chicago Press, 1964) x, 23-25. 
moderate size had appeared. In the West, more than half the population came to reside in towns. Richard Hofstadter has suggested that "the whole cast of American thinking in this period was deeply affected by the experience of the rural mind confronted with the phenomena of urban life." The personal, wellordered, and homogeneous small towns and rural areas from which most native immigrants to urban areas came left them completely unprepared for the chaotic mix of ethnicity and the impersonal crowding of the modern American city. 8

The rise of American industry after the Civil War necessitated a work force more massive than the domestic population could provide, bringing immigrants streaming into the country in unprecedented numbers. Early twentieth century immigration "concentrated heavily on the cities," and dramatically shifted the demographics of urban environments. By 1910, John Higham has noted, over thirteen million foreign-born individuals were living in the United States. However, he asserted that "the immigrants never swamped the older Americans in any major city" despite noting five major cities that were three-quarters foreign born or first generation American. Yet, the cultural impact of the foreign born was tremendous. Immigrants forged "an urban mass culture to replace the traditions they could not transplant intact." The predominance of Protestantism was shattered, urban political machines were created to function on terms of ethnic loyalty, and popular culture was transformed. Such dramatic movements of people and convergence of cultures 
within brief time frames were inevitably chaotic. Consequently, urban areas quickly became a major focus of Progressive ferment. 9

The National Union for Practical Progress provides a clear example of the diverse coalitions quickly established among Progressives to retake the cities at the end of the nineteenth century. By mid-1894, forty cities had formed affiliated chapters of the organization. Paul Boyer has judged the group's goals to be "impossibly diverse, and its tactics nebulous at best." They intended to raise a new moral issue each month through the publication Arena, which had sponsored the formation of the group, and launch "study groups and publicity campaigns" in addition to pursuing political lobbying. Other urban reform organizations were rife in this period, their agenda "vague and concrete results few." Boyer asserted that these groups felt the stakes to be critical and traditional methods to be inadequate. A truly national movement "as dedicated as any religious revival, as coordinated as any military campaign" would be required. He suggested that the most alarmed Progressives took on a 'coercive' stance focused on actively repressing immorality, while others espoused an 'environmentalist' philosophy that would transform "the city's physical environment as a means of elevating its moral tone." In both approaches, a sharp divergence from earlier methods of urban reform was effected. Instead of the volunteerism of the past that focused on reforming individuals, Progressives sought to bring to bear "broad programs utilizing a full panoply of governmental power and aimed at a fundamental restructuring of the urban

${ }^{9}$ Hofstadter, 177; John Higham, Send These to Me: Immigrants in Urban America (Baltimore: Johns Hopkins University Press, 1984) 14-15, 25, 21, 25-27. 
environment."10

The primary method for communicating conditions that required reform to a national audience was the thriving print news industry. For Progressive reform to succeed, a rank-and-file native middle-class was required to vote for reform and support local organizations. While some publications, like Arena, consciously supported Progressivism, many others unwittingly aided the cause by sensationalizing Progressive targets such as urban poverty and political corruption in order to boost sales. Newsprint coverage of urban blight caused increased concern with morality in slum neighborhoods, many of which had appeared quite rapidly as cities dramatically industrialized and grew in population around the turn of the century. And as an increasingly large amount of space was given over to advertisements, newspapers seemed to define their readers as consumers and those who could not hope to obtain the goods displayed upon their pages as 'the other half.'11

Alan Trachtenberg has asserted that "in technologies of communication, vicarious experience began to erode direct physical experience of the world" during the late nineteenth century. He referred to the dramatically expanding newspaper readership in this period as increasingly passive "consumers of images and sensations produced by others." More towns than ever before boasted a newspaper, with the number of daily news publications increasing by almost half and circulation more than doubling between 1892 and 1914. Urban

10Paul Boyer, Urban Masses and Moral Order in America, 1820-1920 (Cambridge: Harvard University Press, 1978) 163-164, 175, 190.

11Alan Trachtenberg, The Incorporation of America: Culture \& Society in the Gilded Age (New York: Hill and Wang, 1982) 126-127. 
newspapers and national magazines found themselves in escalating competition to present the most thrilling stories of adventure obtainable. However, they were hampered by the uniformity of the news reports they shared, taken mostly from increasingly powerful telegraphic news agencies. Yet the many cities that experienced rapid growth and economic change never lacked for local Progressivist drama.12

The stunning early twentieth century growth of Portland, Oregon makes that city a window into the urban transformations of Progressive era America. Between 1900 and 1910, Portland jumped in population from 90,000 to 207,214 (129\% increase), the second highest rate of growth among cities of over 50,000. Yet, despite its vast expansion over a brief period, Portland did not experience any remarkable diversity in sources of immigration. The southern and eastern European immigrants that were streaming into early twentieth century eastern and middle western cities were few in number in Portland. There was a sizable Russian contingent by 1910 (almost 4,000), and a somewhat smaller number of Italians (less than 3,000 ), but other groups that characterized the bulk of immigration in this period were largely absent. In 1910, four of the five largest immigrant groups in Portland were northern European in descent. Many of the

12Trachtenberg, 122; Frank Luther Mott, American Journalism, a History: 1690-1960 (New York: Macmillan, 1962) 547-549; Trachtenberg, 123-124. 
individuals who were moving to Portland did not differ drastically from those who had traditionally lived there. Stephen Janik has found that recent immigrants to the city tended to be middle or skilled working class and relocated to Portland after having already lived elsewhere in America. While many cities that had expanded rapidly battled staggering English illiteracy, Portland's rate in 1910 was merely $1.3 \%$, second best in the nation for a city of its population level. The largest ethnic group was German, comprising only $3.6 \%$ of the local population and not isolated in particular neighborhoods. Similarly, William Toll has found that although Portland had nearly 3,000 Italian immigrants by 1910, they "did not dominate any single neighborhood." The only significant ethnic neighborhood was a two precinct section of the Portland waterfront occupied by Chinese immigrants. 13

Portland's burst of Progressive fervor, unlike that of its counterparts further east, did not feature the sudden shock of heterogeneity as a major causal factor. However, the impact of industrialization on reform is clear. Between 1900-10, the number of Portlanders in personal service occupations declined $39 \%$ and the number of men engaged in agriculture declined $51 \%$. The number of professionals in the city increased $99 \%$ and the number of men in manufacturing increased nearly $230 \%$. Stephen Janik has noted that by 1910 , one of three employed Portland men worked in the manufacturing sector. The dramatic increase in manufacturing not only brought more professionals to the

13Stephen T. Janik, "Prosperity and the Pursuit of Order: Portland, Oregon during the Progressive Era, 1900-1913" B.A. (Hon.) thesis, Harvard College, 1969, 22-23; Paul G. Merriam, "The 'Other Portland': A Statistical Note on Foreign-Born, 1860-1910" Oregon Historical Quarterly 80 (Fall 1979) 266, 268; Janik, 22-23; William Toll, “Ethnicity and Stability: The Italians and Jews of South Portland, 1900-1940" Pacific Historical Review 54 (May 1985) 166-167; Janik, 2223. 
city, but significantly increased the amount of wealth that passed through Portland. Janik used a single fiscal year, 1909-10, to explicate the transition. Over this one year, the value of bank transfers in Portland increased nearly $40 \%$, and that of real estate transfers jumped almost $300 \%$. Portland had become a major commercial center, fourth in the nation in exports. As the level of wealth increased, so did geographical social segregation. By 1915, Portland historian Kim MacColl has pointed out, this trend had become "a fact of life." More than $60 \%$ of Portland's residents lived east of the river, many of whom commuted to the west where commerce was centered and the wealthy lived. The effects of this financial and geographical transformation on the values of the community were tremendous. Janik found a transition from a community composed of independent individuals, to one in which interdependence was inescapable. As self-employment dwindled, reliance on municipal infrastructure services increased, and the scope of vice and corruption expanded, the search for order became frenetic. 14

The campaign to rationalize municipal governance and services in order to eradicate vice and plutocratic corruption characterized Progressive era Portland. A small group of Republican politicians (Portland voter registration was over $80 \%$ Republican) with often formal business ties controlled municipal politics, setting zoning and land use regulations, awarding franchises, and overlooking the legal transgressions of industry and wealthy property holders. Portland was not unique. Contemporary journalist Lincoln Steffens found the 
urban businessman in 1903 to be a "self-righteous fraud" and "the chief source of corruption" who "has failed in politics as he has failed in citizenship." Over the course of the decade, national dissatisfaction with municipal governance prompted a panoply of options for the redesign of state and local politics. In Oregon, initiative and referendum reforms approved in 1902, and the direct primary system passed in 1904, diminished party loyalty and paved the way for Progressive reformers to enter office and fundamentally change the governance of the state. 15

Oswald West, elected governor on the Democratic ticket in 1910, in a thoroughly Republican state and with little money or establishment support, exemplified the decline in party loyalty and surge of reformist passion that emerged in this period. West was but thirty-seven years old when he declared his candidacy and proclaimed in his 'Declaration of Principles' that "the people must rule the corporations or the corporations will rule the State." As State Land Agent and State Railroad Agent he had established a reputation for exposing corruption and eliminating preferential practices.

Yet, the last fifteen member council the city would elect before Progressives swept the institution away in 1913 failed to reflect the success of the West candidacy. The council "was an average chamber of commerce or commercial club group which varied little in character from those of the previous decade except that realtor representation was doubled."16

The vice issue would dominate Portland politics, and Governor West,

\footnotetext{
15MacColl, 6-7; Lincoln Steffens, The Shame of the Cities (New York: Sagamore Press, 1957) 3; MacColl, 7.

16MacColl, 396-398, 401-402.
} 
whose own father had been an alcoholic, would distinguish himself as a tireless crusader. However, the city council and the "colorless" A.G. Rushlight, new Republican mayor and long-serving city councilman, wavered between recalcitrance and ineffectiveness. This contrast would help elicit support for a more professional and non-partisan method of municipal governance. While, in response to public demand, Rushlight had immediately created a fifteen member Vice Commission of the City of Portland, its eventual report, although startling, was filed away and forgotten by municipal authorities. In August 1912 , one year after the ignored vice commission had been created, West declared he would clean up Portland himself. He promised to quit his job if he failed. As the campaign revealed that the owners of property where immoral activity could be found "came from the highest social and business levels in the city," public indignation increased. The city had also tied its financial fortunes to vice, gathering a substantial portion of its budget from granting liquor licenses. The issuance of 500 of these permits in 1900 provided half of city revenue for that year. Yet, despite public outrage, the Vice Commission seemed divided and powerless. It had become "bogged down in the old dispute over whether the profession [of prostitution] should be banned or limited to a restricted district." Rushlight favored the latter option as "better than present conditions," but felt that the Commission should not have the power to implement such a scheme. 17

The result of the exposure of vice corruption, and growing anger over

17MacColl, 402-411, 13; Gloria E. Myers, A Municipal Mother: Portland's Lola Greene Baldwin, America's First Policewoman (Corvallis: Oregon State University Press, 1995) 104. 
the complicity of the city council in placing corporate interests above those of citizens in zoning and granting franchises brought about a revolution in 1913. The Galveston Plan was approved in May and instituted after the election of local officers the following month. According to this new charter, the part-time fifteen member city council would be replaced by four full-time commissioners, each in charge of a city department assigned to them by the mayor, who also would have charge of a department (intended to be the police). All five individuals would hold equal voting power, without veto, and each would be elected by the entire city through a non-partisan preferential voting system. In an effort to keep industry out of municipal administration, all citizen boards would be abolished. 18

The city had, by only 722 votes, chosen a system that would dramatically reduce corporate cronyism and partisan brokering. Low voter turnout may well have been a decisive factor in the victory, caused in part by the decline of local party organization. However, Janik's research clarifies from which social groups support for the new charter came. In a study of voting records by precinct, he has concluded that the most substantial support came from the middle and laboring classes, with upper and lower class individuals alike registering less support. He indicated that while Progressive attempts at social control received most support from the upper classes, schemes to limit the power of special interests were most heavily supported by the middle and laboring classes. The latter groups continued their electoral success in 1913 with the election of Progressive H. Russell Albee, advocate of "municipal

18 MacColl, 442. 
ownership of public utilities," to the office of mayor in a repudiation of both major parties. 19

Albee's administration, like Rushlight's, would be plagued by the high profile of the vice problem in Portland. In 1913, the state legislature passed the 'Abatement Law' championed by Governor West that would hold individual owners liable for immoral businesses on their property, even those carried out without their knowledge. In addition, because "common fame was sufficient evidence of guilt," the alleged immoral practices did not have to be proven with hard evidence. Penalties were harsh, and the District Attorney filed sixty-eight cases within eighteen months. The Albee administration hoped to build a detention facility to accommodate the "unfortunate women" streaming into the justice system, and appropriated $\$ 15,000$ in the 1914 budget toward this end. Although the city did purchase a site, construction funds did not materialize until 1918, and only then as the result of federal pressure to protect nearby troops from venereal disease. In its ineffective anti-prostitution zeal, Portland was not alone. Boyer noted that although 102 cities engaged in thorough vice investigations between 1902 and 1916, it is not apparent that there was much long-term success in controlling the problem. 20

19MacColl, 444-445; Janik, 82, 86; MacColl, 445.

20MacColl, 459-461; Myers, 124-125; Boyer, 195, 217-218. 
New York was the first major American city to formally investigate the extent of its prostitution trade, creating a 'Committee of Fifteen' which published its shocking results in 1902 and became a model for other cities who would go on to pursue similar efforts. As the campaign swept American cities and inspired national coalitions, rhetoric reached increasingly fierce levels. Boyer noted that the moderately worded report of New York's 1902 commission was followed by increasingly polemical ones from other cities and national groups. All three of Rodgers's languages of Progressivism seem to converge upon this issue. Boyer traced a shift in the anti-prostitution campaign from 'social purity' to 'social hygiene,' its rhetoric "suffused with public health terminology." Here, the language of the moral reformer, social unity, converged with that of the Progressive technocrat, social efficiency. The desire for tangible results to an enormous problem required language that could convey actual progress, hence moral reformers sought out technical experts and utilized their methods of operation and standards of measurement. Antimonopolism was also strongly present, for the crusade "displayed less interest in the nation's general level of sexual morality than in a limited phase of the subject: largescale commercial prostitution." According to New York's director of investigations for the Committee of Fifteen, George Kneeland, the prostitution trade was comprised of "whole networks of relations ... elaborated below the surface of society." The implication was clearly that prostitution was a shadowy trust to be exposed and broken up, rejuvenating urban morality. 21

Boyer has contended that to Progressive reformers 'saloon' and 'brothel'

21Boyer, 103, 211, 199-201, 206, 209. 
were often "simply code words for the larger menace of urban social change." The primary cause of urban immigration, rapid industrialization, played perhaps the greatest role in dramatically changing social and cultural life in America's urban centers. Portland's massive population growth and expansion of manufacturing enterprise over a single decade indicates an unprecedented level of geographic mobility and must have resulted in similarly new possibilities of urban anonymity. As women poured into the industrial sector for the first time, maintenance of traditional standards of morality in the face of this cataclysmic change received strong attention. From his studies of contemporary interviews with urban prostitutes, Boyer has found that "the lure of the city, the fascination of activity and glitter ... , the drive to achieve a higher living standard, the unwillingness to pass one's life in subservient, deferential roles" were the primary causal factors leading women into prostitution. He continually came across "spirited women who have chosen prostitution in preference to boring, demeaning, or otherwise intolerable situations." Although reformers referred to it as 'white slavery,' "many of the women themselves" described their entry into the occupation as "a liberating escape from bondage."22

J.J. O'Connor, who worked for the San Francisco courts in 1913, told the press he believed that "the small wages paid girls are the basic reason for most of the girls that come to us from the dance halls, the resorts, and the streets." $\mathrm{He}$ recounted the typical case in which a girl would leave the repressive life of domestic service to work in the department stores. While earning only $\$ 4$ to $\$ 6$

22Boyer, 210, 203-204. 
per week there, and "surrounded by things they longed for," the drift to prostitution was common in such environments. The role of the sinister foreigner was often emphasized in luring these young women into a debauched life. Clifford Roe, a nationally known anti-prostitution crusader, concluded that "native-born women were at the mercy of the foreign pimp." Fully threequarters of white slaves "have been inveigled from our own farms, homes, towns, and cities; but it was the foreigner who taught the American this dastardly business." Frederick Grittner has found that the "country-girl-towhite-slave" idea encapsulated anxieties surrounding the increasing geographic and economic mobility of women developing concurrently with the rapid ethnic transformation of urban life. 23

Importantly, Roe defined 'white slavery' as the procurement of women "with or without their consent" to serve as prostitutes. For examples of voluntary prostitution were rife. While the shop girls $\mathrm{O}^{\prime}$ Connor cited were making less than $\$ 1$ per day, the Portland Vice Commission found in 1912 that in some cases prostitutes were making at least $\$ 25$ to $\$ 30$ per day. Ruth Rosen noted that only $7.5 \%$ of over 6,000 prostitutes interviewed in a variety of studies throughout the Progressive era reported 'white slavery' as the cause of their entry into the occupation. Rosen has found that this causal myth served "to deflect attention away from the very real social and economic factors that led women into prostitution." But perhaps most importantly, she asserted that it "emphasized women's passivity" in the transformative process from pure to

23Oregon Journal, July 24, 1913, p. 2; Frederick K. Grittner, White Slavery: Myth, Ideology, and American Law (New York: Garland Publishing, 1990) 66-68. 
prostitute. Yet, in confirmation of Boyer's research, Rosen emphasized that "most women chose to enter prostitution," and that their motivations were primarily economic. 24

Deep seeded fears of the moral chaos seemingly implicit in the social revolution brought on by industrial urban life spurred a nation-wide minimum wage movement to ensure that women would be able to support themselves and live in a moral fashion. Clergyman Edwin O'Hara, Chairman of the Industrial Welfare Commission of the State of Oregon (formed in 1913) clearly eliminated the prostitution problem as a motivation for the minimum wage investigations undertaken by his commission. Yet the very fact that $\mathrm{O}^{\prime} \mathrm{Hara}$ sought to eliminate low wages as a causal factor of prostitution indicated that the idea had a certain currency. In addition, the Commission emphasized immorality as a result of low standards of living. The first section of its concluding report outlined five reasons why the state had a responsibility to regulate this aspect of private life: economic evils, social evils, domestic evils, individual demoralization, and national weakness. O'Hara's defense of items two through four employed such phrases as: "the deterioration of public morals," "moral temptation," "disintegration of family ties," "growth of

24Grittner, 67; Second Report of the Portland Vice Commission: On Certain Aspects of the Commercialization of Vice, August 1912, p. 65, Stanley Parr Archives and Records Center, Portland, Oregon; Ruth Rosen, The Lost Sisterhood: Prostitution in America, 1900-1918 (Baltimore: Johns Hopkins University Press, 1982) 133, 137, 145. 
parental irresponsibility," and "greater moral strain." The Chairman primarily seemed to deny the connection between low wages and female immorality on the grounds of political impracticality. He noted the failure of this tactic in every state where it had been overtly named as the leading motive for minimum wage legislation, dismissing it as "a gratuitous insult to ... thousands of underpaid women workers." O'Hara claimed that the image of "underpaid women workers ... denying themselves the necessities of life in order to lead lives of virtue" would serve as "a more substantial argument" to sway the public. 25

Yet on the matter of low wages leading to prostitution, O'Hara had to endure contemporaries who would not be silenced. Emma Goldman, a radical socialist and anarchist, wrote in 1910 that "the merciless Moloch of capitalism that fattens on underpaid labor" had driven "thousands of women and girls into prostitution." Yet, "naturally our reformers say nothing about this cause" although "they know it well enough." She raged that "it is much more profitable ... to pretend an outraged morality, than to go to the bottom of things." Goldman also referred to repressed sexuality as a causative factor of prostitution, in clear contradiction to the passivity and victimization inherent in the Progressivist concept of 'white slavery.' The much more moderate Progressive reformer Jane Addams wrote in 1912 that the recently released Chicago Vice Report indicated that prostitutes made over four times more than women in "honest work." She worried that, in addition to exceedingly low

25Edwin V. O'Hara, A Living Wage by Legislation: The Oregon Experience (Salem, OR: State Printing Dept., 1916) xix-xx, iii-iv, xix-xx. 
wages, the brutality of industrial life and its effect upon the family was also a strong causative factor. Women could not "proportion their hours of work and intervals of rest according to their strength" which meant that "the effort to obtain a livelihood fairly eclipses the very meaning of life itself." 26

Perhaps the period's most extensive legal brief on this issue was that of Louis Brandeis, whose landmark victory in Muller v. Oregon (1908) opened the floodgates to women's protective labor legislation. Brandeis successfully defended Oregon's law limiting women employees to a ten-hour day. Significantly, his brief made substantial reference to the negative effects of long hours upon morality by maintaining that "the effect of overwork on morals" was "closely related to the injury of health." Brandeis cited the testimony of a mule-spinner in a cotton mill who claimed to "have noticed that the hard, slavish overwork is driving those girls into the saloons, after they leave the mills evenings." He also referenced the writings of British social scientist Beatrice Webb, who maintained that contemporary industrial life revealed "the invariable coincidence of a low standard of regularity, sobriety, and morality, with the conditions to which women, under free competition, are exposed."27

Both Brandeis and O'Hara implied that the state must now provide the steady paternal guidance lacking in contemporary society. Contemporary jurisprudence would side with them. In his decision in Muller $v$. Oregon, Justice Brewer stated:

26Emma Goldman, Anarchism and Other Essays (New York: Mother Earth Publishing Association, 1910) 184, 190; Jane Addams, A New Conscience and an Ancient Evil (New York: Macmillan, 1912) 56-58.

27Leon Stein and Philip Taft, introduction, Women in Industry, by Louis D. Brandeis and Josephine Goldmark (New York: Arno Press, 1969); Brandeis and Goldmark, 44-46. 
That her physical structure and a proper discharge of her maternal functions - having in view not merely her own health, but the well-being of the race-justify legislation to protect her from the greed as well as the passion of man. The limitations which this statute places upon her contractual powers ... are not imposed solely for her benefit, but also largely for the benefit of all.

Inherent in such thinking was the notion that female participation in the industrial work force should be viewed as regular employment because women often were entering the manufacturing sector to sustain themselves or a family. $\mathrm{O}^{\prime}$ Hara stressed that if his contemporaries did not recognize that women no longer viewed industrial occupations as 'pin money,' or purely transitional work, but as their primary means of sustenance, future consequences would be dire. It could no longer be assumed that individual men would care for women. Thus, the state was to take on such responsibility in a regulatory capacity. If not, basic feminine biological and social roles would crumble, rending the moral fabric of society. 28

Alice Kessler-Harris has noted that the investigations of such state commissions in the Progressive era were "heavily reliant on language and imagery that reduced women to perpetual girlhood" and "included almost nothing beyond the barest sustenance." Most employers refused to believe that women required wages to support either themselves or a family on a long-term basis, for the concept of the living wage was explicitly male. Kessler-Harris has cautioned that this idea should be seen as a social, not theoretical economic, construct. "Because the living wage idealized a world in which men had the privilege of caring for women and children, it implicitly refused women that 
privilege." Yet, Kessler-Harris has found, women were a quarter of the industrial workforce in the beginning of the twentieth century. More than onethird of working women lived independently of their families, and threequarters of those who lived at home contributed earnings to support their family. Although an entirely new wage idea was needed to reflect the social structure of industrial America, reformers were motivated by "a desire to protect the home, not from ... antagonism to the pitiable condition of those women who worked for wages." The earnings of working women, they believed, should not be "so generous as to tempt those in families to live outside them."29

Trade unionists in this period displayed a similar hesitancy in adjusting to the social reality of contemporary industrial life. Although the number of women in the workforce doubled between 1890 and 1910 (from four to eight million), the organization of women in trade unions did not reflect this trend. Philip Foner cited Leo Wolman's estimate of 73,800 female trade unionists in 1910 , less than $1 \%$ of the total number in the workforce. Kessler-Harris has found a slightly higher percentage for that year (1.5\%), but still equally negligible. Foner has written that although "year after year the A.F. of L. passed resolutions calling for the organization of women workers," their policies in this period reveal a great deal of ambivalence concerning such recruitment. When the women of Pontiac, Illinois engaged in the shoemaking industry expressed an interest in joining the Boot and Shoe Workers, they quickly became

29Alice Kessler-Harris, A Woman's Wage: Historical Meanings and Social Consequences (Lexington: The University Press of Kentucky, 1990) 13, 7, 10-13. 
disillusioned: "we voted by a large majority not to go in as the dues were to[o] high, and we simply do not earn enough to pay them." Foner cited Brissenden's contemporary wage estimates of women workers, finding an annual average of $\$ 339$ in 1909 , compared with $\$ 631$ for men. The AFL often appeared to be calling for the widespread organization of the working class, but dues of $\$ 1$ to $\$ 5$ per month and initiation fees ranging from $\$ 25$ to $\$ 500$ made union representation cost prohibitive for many workers. 30

Kessler-Harris has actually found a trend of declining trade union access for women at the turn of the century. The percentage of unionized women in industrial occupations declined from $3.3 \%$ in 1900 to $1.5 \%$ in 1910 . Her research is confirmed by Foner's earlier work. Between 1903 and 1908, he has noted, the number of women trade unionists in Chicago declined from over thirty thousand to just ten thousand. Foner cited the disgust of women workers with the hostile attitude of AFL craft unions as perhaps the major cause of this decline. This contempt seems to have been mutual, for while some international unions declared their intent to organize women and to reduce their membership fees, many locals within these unions merely disregarded these directives. The notion that women entered industry only temporarily, and to earn spending money rather than a living wage, was pervasive among AFL leaders. They felt, therefore, that it would be a waste of resources to organize workers who would not play a long term role in trade unionism. The Women's Trade Union League, organized in 1903, attempted to overcome opposition to

30Philip S. Foner, History of the Labor Movement in the United States, Volume III: The Policies and Practices of the American Federation of Labor, 1900-1909 (New York: International Publishers, 1964) 221-222; Alice Kessler-Harris, Out to Work: A History of Wage-Earning Women in the United States (New York: Oxford University Press, 1982) 152; Foner, 221-222. 
organizing women within the AFL, but the organization merely "greeted the new venture politely, and its leaders gave it lip-service support." At the tenth anniversary convention of the League in St. Louis during June 1913, provisions for training women organizers and making skilled craft training available were prominent concerns. However, Foner noted that although the League worked extensively to prepare women to enter the AFL, union locals often failed to follow-up with recruitment. 31

Victor Morris wrote, in 1930, that the unionization of women in Oregon was as scant as such efforts in the rest of the country. He found a number of reasons why, although "the organization of women into unions has been attempted," it has not met with success. He found women laborers to be younger, on average, than male laborers, which conspired with their entry into "industry in large numbers" as a "comparatively recent development" to render them more inexperienced as a group than their male counterparts. However, "a more fundamental reason for their weakness" was the temporary nature of their involvement in industrial work. In addition, he noted that organization requires "financial strength and women represent the very lowest paid groups." He also blamed concentration in unskilled lines of work and the opposition of employers. 32

However, Morris seemed fully aware of the need to sustain a living wage for women in industry. He asserted that although current participation in industrial life among women was often a precursor to married life, or a result of

31Kessler-Harris, 152; Foner, 223-229; Portland Labor Press, June 16, 1913, p. 3; Foner, 230.

32Victor P. Morris, Oregon's Experience with Minimum Wage Legislation (New York: AMS Press, 1968) 65-67. 
desperate circumstances later in life, "this is probably a slowly disappearing characteristic and that as modern life develops more completely women will become permanent factors in the laboring class." He also believed that "most women are in industry by force of necessity; their jobs are vital to them." Maintaining, however, their inexperience and lack of financial resources and craft skills, Morris asserted that in the face of hostility from both the labor establishment and employers the state had been justified in entering the bargaining process on the side of women workers. Although organization among women might be a viable alternative in the future, the seriousness of "immediate conditions" called for other methods to "give improved bargaining strength to women." He indicated that "analysis of the process of bargaining through the Industrial Welfare Commission [of Oregon] shows that it overcomes these weaknesses inherent in unionization of women." "To the strength of women is added the strength of the state." Because women lack "initiative," "organizing ability," and "resisting power"due to their current state as an impoverished and unrepresented group within industry, the Industrial Welfare Commission was to become their active representative, initiating and fighting for improvements in their situation. 33

Although women in the fruit canning industry desperately required

33Morris, 66-67, 70-71. 
better wages and conditions, state intervention was minimal. This industry provided seasonal work, with June to October roughly comprising the period of highest employment in Oregon. The average number of laborers in the state varied widely according to the time of year, from 246 in March to 1,495 in October. Because of the urgency of preserving fruit before spoilage, these establishments were exempt from the state's maximum work hours legislation, the most common work week comprising fifty-four hours, but ranging up to seventy-two. Because the work offered long hours over a brief period in an unskilled job, many of those who chose it were women with family obligations, workers who presumably required a great deal of flexibility in their working life. In Oregon's fruit and vegetable canneries in 1914, over half the workforce was female. This was a recent trend; in the canning industry as a whole, the workforce had been $61 \%$ male in 1909 , reduced to just under $50 \%$ only five years later. 34

During the 1923 fruit picking and canning season in western Washington state, the Women's Bureau of the Department of Labor conducted a thorough survey of females engaged in that industry. Their findings indicated, as David Montgomery asserted, that "a woman's wage earning was most often limited to the years before the birth of her first child." However, Montgomery also noted that the highest proportion ever of American women who never married was born between 1860 and 1900 . These women would have been between nine and

${ }^{34}$ Census of Manufactures, 1914 (Washington: Government Printing Office, 1919) 370-371; Women in the Fruit-Growing and Canning Industries in the State of Washington: A Study of Hours, Wages, and Conditions (Washington: Government Printing Office, 1926) reprinted in Dan McCurry, ed., Cannery Captives: Women Workers in the Produce Processing Industry (New York: Arno Press, 1975) 35-36; Census of Manufactures, 366, 369. 
forty-nine years old in 1914, a period when the Oregon canning industry seems to have been rapidly feminized. A decade later, in western Washington, that same generation (now between nineteen and fifty-nine) comprised over threequarters of the female component of the fruit cannery workforce. In clear confirmation of Montgomery's research, $40 \%$ had never married. In addition, $17.2 \%$ of the cannery workforce was either widowed or divorced. It is clear that women of this generation required a living wage in order to survive. 35

Of the 2,591 women reporting in the 1923 Women's Bureau survey, 950 described themselves as 'daughter' or 'sister' rather than 'wife' or 'mother.' Yet, almost three-quarters of the total number of women were twenty-five or older. Family ties, even among the unmarried, appear as a major causal factor of taking work. Not a few women had a great deal of responsibility for sustaining their families, 322 reporting that there were no male wage earners in their family (the greatest portion of these women, 183, worked in fruit canneries) and 147 reporting that they were the sole wage earner of the family (the greatest number, 92, also at fruit canneries). Over half the total number of women surveyed "stated that they were working to help meet the expenses, or supply the necessities, of the home and family." 36

Yet, low wages, irregular hours, and appalling working conditions made cannery work a brutal and ineffective means of support. Of the eighteen canneries in western Washington that the Bureau inspected, only a quarter had

35David Montgomery, The Fall of the House of Labor: The Workplace, the State, and American Labor Activism, 1865-1925 (Paris: Cambridge University Press, 1987) 137, 141; McCurry, 22-23.

36McCurry, 26, 22, 28. 
wash basins with hot water and one-third did not provide towels. Only three factories boasted sanitary drinking fountains, and less than one-third of the canneries had a toilet for at least every twenty women (some only provided one for every thirty to sixty women employed). Although the Bureau stated that due to "the nature of cannery work, a dressing room in which to change clothing seems essential," they were often absent or combined with other facilities such as lunch rooms or bathroom and washing areas. Almost a third of the canneries surveyed failed to provide lunch rooms, and over half lacked rest rooms. 37

Only $10 \%$ of the women listed choice as the reason for seeking employment in the industry, specifically to "earn spending money" or for "the chance to work with their friends." That this number is so small is unsurprising, considering the grueling nature of the work. Montgomery suggested that "for wage-earning women, as for most teenage boys, work was most unlikely to become the central concern of their thoughts and dreams." A working life was a necessity for many in this generation of women who quite often were maritally unattached, with more than a few lacking male wage earners to rely upon. Nowhere within the fruit industry was this more true than in the canneries, where nearly half of the women in the Bureau survey that reported they worked to support themselves were employed. The fight within this industry for a living wage was clearly an issue of survival, but the seasonal and unskilled nature of the work exacerbated continuing doubts within the labor

37McCurry, 99-100. 
establishment concerning the organization of women. 38

38McCurry, 35; Montgomery, 143; McCurry, 28. 
Chapter IV

Oregon Packing Company Strike of July 1913 
Just three days after the Industrial Welfare Commission of Oregon began an investigation of Portland factories to the end of establishing a minimum wage for women, a group of women workers participated in a spontaneous walkout at the Oregon Packing Company. Both the Morning Oregonian and the Oregon Journal, the morning and evening papers with the widest circulation in Portland, estimated that fifty women walked out of the fruit cannery on the morning of June 27 . The Journal reported that the women involved in the protest were part of a work force 200 strong and had just begun work as cherry stemmers that morning. After three hours of work, some of the women had discovered that at the pay rate of $10 \propto$ per box of cherries stemmed and sorted, they were earning only between 5 and $8 \notin$ per hour. A group of forty pickers left their work to raise the matter with Superintendent McPherson, overseer of the plant. He refused to raise wages, instigating an immediate walkout by the group and ten women who joined them on their way out. The women called upon a local branch of the Socialist Party, who sent organizers over to the plant. The IWW quickly became aware of the strike and also sent help.1

With the assistance of local socialists and Wobblies, the striking women immediately began a protest outside the main entrance to the plant, carrying banners and attempting to draw the rest of the women out. The Superintendent quickly raised the rate for cherries from 10 to $15 \notin$ per box. "They had to," one striker asserted, "or practically every one of the girls would have walked out." The Daily News, the only Portland newspaper of significant circulation to

${ }_{1}^{1}$ Morning Oregonian, July 4, 1913, p. 16; June 30, 1913, p. 7; Oregon Journal, June 30, 1913, p. 2. 
support the strikers, announced that "it is planned to start a union of the girls if possible." The paper attempted to arouse a sense of inevitability concerning the strike by exaggerating the size of the walkout and declaring that more were quitting every hour. Yet, there may well have been truth in the paper's assertion that "many others applying for work join the strikers when told of the conditions." To pass through the door to the plant, women who had no connection with the cannery would have had to pass through a gauntlet of angry strikers, radical organizers, and sympathizers. The typicality of Oregon Packing Company conditions and the rarity of significant strike action in such concerns may have instigated some amount of solidarity between the protestors and women seeking work. During the first several days of the strike, the action remained a spontaneous protest without formal representatives or demands beyond increased wages. 2

Nevertheless, organization quickly followed. The News reported that a woman who lived near the cannery offered both her home and telephone to the strikers for the establishment of a headquarters later in the day of the walkout. That evening, Tom Burns, an English immigrant and local radical of eclectic socialist views, delivered a street lecture in downtown Portland describing conditions at the cannery and proclaiming the existence of a strike. He collected $\$ 12.75$, the beginning of a strike fund. On June $29, \$ 82.60$ was raised on behalf of the women by local socialists at a similar event, and although it is unclear whether or not Burns was present, he quickly emerged as the leader of a hastily formed strike committee. It is likely that his leadership emerged during a

\footnotetext{
2Journal, June 30, 1913, p. 2; Daily News, June 28, 1913, p. 1.
} 
meeting held at the local Socialist hall on the evening of June 30, during which the News claimed "an effort will be made to organize the girls so that they can carry on their campaign more effectively." On July 1, although the packing company refused to negotiate with the strike committee, the police met with the group to clarify the parameters of the protest. Ominously, the strikers made a threat to fill the jails if 'free speech' was denied them. ${ }^{3}$

In the wake of the meeting at the Socialist hall, formal demands were issued. Two of these demands, $\$ 1.50$ per day for laborers and $25 \notin$ per hour for forewomen, indicated the unusual nature of this strike. Women were grouping together in a way that belied traditional work hierarchies. Work conditions featured prominently. The women demanded a lunch room, sick room, dressing room, lockers, three aprons per worker per week, and sufficient towels. Current conditions were claimed to be intolerable, with five wash basins for the entire plant and lavatories that were "insufficient and unsanitary." J.D. Edmunds, whose identity and connection to the strike is unclear, wrote a lengthy description of plant conditions to Mayor Albee on July 6. He asserted that if the women complained about their wages they are "lered at and will be answered that; you are a good looker; and can do business on the side and make a good living - all the girls do that." Edmunds also maintained that women were fired for taking leave during menstruation and fined $25 c$ for eating a piece of fruit. He noted that the toilets were "dirty unsanitary hovels not fit for a hog," forcing the women to use toilets in private residences near the plant, and that the towels and sinks were "positively filthy." Although the 
mainstream press continually stressed the wage aspect of the strike, conditions in the plant were clearly a crucial factor in the walkout. In addition, the women demanded a nine-hour day (the plant was operating on a ten and one-half hour day), duplicate time slips, and a promise that strikers would not be discriminated against after settling their grievances with the company.4

The Industrial Welfare Commission quickly became involved in the dispute on behalf of the striking women, but the manner of their initial involvement is unclear. While the Journal claimed that a delegation of strikers called upon Chairman $\mathrm{O}^{\prime} \mathrm{Hara}$ and the Commission on June 30, only four days into the protest, the News reported that the strike committee found their interference entirely unwelcome. Burns stated that "the Industrial Commission which butted into this affair is composed mostly of parlor reformers, and it seems to me that their principal function is to break a strike and not assist in ameliorating the conditions of the helpless workers." J.D. Edmunds confirmed Burns's reaction, asking in his letter to the Mayor: "is it not the strikers place to ask for a living wage, and make there own agreement with the company[?]" On July 1 , the day after the delegation of strikers reportedly called upon the Commission, a three hour inspection took place after which R.D. Fontana, plant manager, agreed to a payment system of $\$ 1$ per day minimum and extra for all piece work above the value of $\$ 1$ at $15 \notin$ per box. The Journal confidently reported that "with this new rate in effect it is believed that all of the women and girls who walked out will go back." In addition, Fontana promised to

\footnotetext{
${ }^{4}$ News, July 2, 1913, p. 1; July 12, 1913, p. 1; J.D. Edmunds, letter to H.R. Albee, July 6 , 1913, Mayor's Subject Correspondence, Stanley Parr Archives and Records Center, Portland, Oregon; Joumal, June 30, 1913, p. 2; News, July 2, 1913, p. 1.
} 
improve restrooms and conveniences. The shorter day, however, was rejected out of hand. At the beginning of the strike, Superintendent McPherson pleaded the company's financial position to the press, stating that "this business is at present making little or no money." He justified the low wages, also, with his belief that "virtually every woman working as a picker does not have to work for her support. Many of them are girls who want to make some extra pin money."5

The Commission stressed that the agreement, although not ideal, "offers immediate relief" whereas legal action could not be initiated and concluded within the current fruit packing season. They also noted that the improvement in wages was "notable" and other factories were only paying between $\$ 3.50$ $\$ 4.50$ per week, making $\$ 6$ "not unreasonable comparatively." The Commission hypothesized that too high of a minimum would prevent the hiring of any women other than those of very high efficiency, barring aged or infirm women from the industry (although they had actually negotiated to let a certain number of such women work as exemptions from the minimum). Still refusing to meet with the strike committee, Fontana selected a business associate, H.M. Haller, to act as intermediary in presenting the compromise to the strike committee. The strikers rejected the agreement, in which they had not participated and which ignored or failed to meet virtually all of their demands. The immediately negative reaction of the strikers to the inspection and compromise discredits the frivolous motivations for working ascribed to the

5 Joumal, June 30, 1913, p. 2; News, July 4, p. 1; Edmunds to Albee, July 6, 1913; Joumal, July 1, 1913, p. 2; Oregonian, July 4, 1913, p. 16; Joumal, June 30, 1913, p. 2. 
women by Fontana. The Journal's claim that the women themselves had solicited the help of the Commission is also thrown into question. 6

This indication that the strike had the potential to become a protracted conflict spurred the Mayor to take a firm position regarding methods of public protest. The strikers were contending with a new administration, the first under the new city charter, which had just taken office on July 1 . The News declared that "a decided change was noticeable in the attitude of the police authorities," portending confrontation. Handling the strike would be the first serious test of the viability of the city's new organization and Progressive administration to maintain order and judge grievances in the context of public opinion. On July 2, the Mayor laid out his guidelines. "There will be no bar to free speech in the streets as long as I am mayor, and that is positive." However, "what I do object to and will not permit is the nasty and insulting language that some of the street speakers in the city have been resorting to." The theme of enforcing a community standard of obscenity would resound throughout the conflict. He also defended the right to picket and emphasized the importance of street speaking "to people of the working classes who cannot afford to hire halls to speak in." The following day, the Mayor made a visit, incognito, to the site of the strike after an anonymous phone call warned his office of unrest. Albee found the behavior of the crowd perfectly satisfactory, noting that "there were policemen on hand, but the strikers themselves were preserving order."7

6 Joumal, July 3, 1913, p. 2; July 1, 1913, p. 2; News, July 3, p. 1.

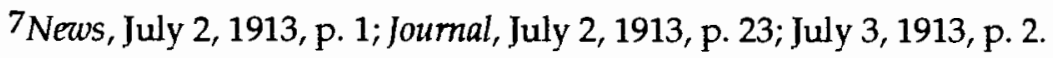


However, the stakes were being raised as the protest continued to interfere with the smooth operation of the cannery. The News reported on July 4, two days after the Mayor's visit, that local residents had been approached by representatives of the plant and asked to complain of unrest to police headquarters, and claimed that troublemakers had been placed in the crowd. J.D. Edmunds confirmed these accusations in his letter to the mayor. However, at this point, it seems the paper's accusations that plainclothesmen in the area were looking for any excuse to begin making arrests seems unfounded. But the following week, on July 8 , the confrontation began a two day period of sharp escalation. In the morning, eleven women who had remained at work at the cannery were driven to the Mayor's office to claim abuse at the hands of the striking women. The tactic was soon discovered, and a large group of strikers and sympathizers marched from the plant to City Hall to present counterevidence. The number in the group remains unclear; the Oregonian estimated 200, and the News 100, while the Journal claimed only fifty. It is clear, however, that Burns led the group and IWW and Socialist Party men were in attendance. After this second group of women arrived, the Mayor was forced to move the meeting from his office to the council chamber to accommodate the large numbers. Women who wished to testify concerning the conditions in the plant and the conduct of the strike were sworn in by City Attorney LaRoche. Both sides claimed they were receiving abuse from the other, and differed sharply in 
their descriptions of plant conditions. 8

Later in the afternoon, Superintendent McPherson arrived with a group of delegates (again, of indeterminate size; the Journal claimed fifty while the Oregonian noted only thirty) from the East Side Business Men's Club demanding action to quell the disturbance. It was now impossible to conceal the damage the strike had done to the company. McPherson and Fontana claimed that if the strike continued, business would have to be transferred to their plant in Salem at close of business on Saturday. They noted that 300 women had been employed before the disturbance, but the female workforce had been reduced to 150 . This indicates a total of 150 strikers, a number confirmed by the News several days later. The plant managers tried to shift blame for the growth of the strike to the protestors themselves by reducing their estimate of the initial walkout to twenty, although both the Oregonian and the Journal had recorded fifty. The plant had clearly lost a great deal of money. The day before the conference in the council chamber, 200 boxes of cherries lay rotting at the entrance for lack of women to stem and sort them. On the morning the group of loyal workers was driven to the Mayor's office, five wagons full of fruit were hauled away from the plant unprocessed. Several days later, Superintendent Otis of the city crematory stated that his facility had burned fifteen tons of cherries in the past week, most of them delivered from the Oregon Packing Company. City Commissioner Daly arranged to have excess fruit sold in the streets to minimize waste and financial loss. Overall, the

${ }^{8}$ News, July 4, 1913, p. 1; Edmunds to Albee, July 6, 1913; News, July 4, 1914, p. 1; July 8, 1913, p. 1; Oregonian, July 9, 1913, p. 10; News, July 8, 1913, p. 1; Joumal, July 8, 1913, p. 15; Oregonian, July 9, 1913, p. 10. 
company claimed $\$ 5,000$ dollars had been lost so far. 9

Mayor Albee could certainly identify with the businessmen who called upon him that afternoon, for he had "entered the the lumber business in Bay City, Mich., as a young man and soon became owner of a manufacturing lumber plant." He arrived in Oregon in 1897 as Portland manager of the Northwestern Mutual Life Insurance Company. Although he had been a member of the City Council from 1902 to 1905 and served in the State Senate in 1909 and 1911 before becoming mayor, Albee had spent much more of his career in the business world than as an elected official. After the visit from the East Side Business Men's Club delegation, a significant shift of policy toward the disturbance is evident. Previously satisfied with the conduct of the strikers, Albee issued a statement that if any laws were broken arrests would be made, seemingly anticipating this outcome. Indeed, the day after the conference, the first arrests occurred. While picketing, Mary Schwab, wife of IWW organizer Rudolph Schwab, was arrested twice (the News claimed four times) on disorderly conduct charges. Her husband and another sympathizer, Henry Schoen, were also arrested. For the Schwabs, this would be the beginning of a protracted legal battle. Mrs. Schwab's second arrest was instigated by an employee of the plant who had a warrant issued for her on the charge of using "violent and abusive language." The latter arrest would characterize those that followed. The following evening, July 10, Mayor Albee instructed Chief of Police Clark that strikers were no longer allowed to congregate in front of the

\footnotetext{
${ }^{9}$ Journal, July 8, 1913, p. 15; Oregonian, July 9, 1913, p. 10; News, July 10, 1913, p. 1; Oregonian, July 9, 1913, p. 10; July 11, 1913, p. 1.
} 
plant and that the protest would have to be moved to a vacant lot one block away. In addition, all speaking in the lot would end at ten in the evening. However, it is quite possible that the police interpreted the statement Albee released after the conference as license to start making arrests and the Mayor was thus reacting to a situation that had heightened legal implications. The first day of arrests had already been followed by a second, in which three women strikers were taken into custody, seemingly forcing the mayor to retract his former liberal policy concerning picketing and speaking. In addition, the IWW held a street meeting in the evening on the second day of arrests that lasted for quite some time, with spectators causing traffic congestion, requiring the police to break up the crowd. Frustrated, Albee stated that "I have given the strikers every possible opportunity to do the right thing, and they seem to be disregarding my instructions entirely." 10

Causing the Mayor even greater chagrin, Governor West decided to come to Portland to negotiate a settlement and inspect the protest. On July 11, upon arriving at the vacant lot now occupied by the strikers and their sympathizers, West engaged Tom Burns, who was addressing the crowd, in an angry dialogue. Burns, apparently, had threatened that the strikers would close the plant down, a statement to which West seemed to take great exception. He mounted a tar barrel to shout Burns down, and then successfully offered to negotiate a settlement at City Hall the following morning if the strikers agreed

\footnotetext{
10Anonymous article, 'Mayors - Portland' Vertical File, Oregon Historical Society, Portland, Oregon; E. Kimbark MacColl, Merchants, Money and Power: The Portland Establishment, 1843-1913 (Portland, OR: Georgian Press, 1988) 448; Oregonian, July 9, 1913, p. 10; July 10, 1913, p. 11; News, July 10, 1913, p. 1; Oregonian, July 10, 1913, p. 11; July 11, 1913, p. 12; Journal, July 10, 1913, p. 1.
} 
to stop picketing until then. Seemingly at wits end, the Mayor struggled to appear in control of the strike. "I have given my last warning. If it is not heeded my next action will be to direct the Chief of Police to stop all speaking in the streets." The strikers had already made clear what their reaction to this policy would be. 11

The Journal reported that "never in the history of the city hall did such a crowd press into its council chamber. There was no room for chairs, standing room was at a premium." The most dramatic moments of the July 12 meeting concerned the Industrial Welfare Commission. Burns, still resentful of the body's interference, shouted allegations of its dishonesty, to which West and Chairman O'Hara both responded. West leapt upon the mahogany council table and, as he had done the day before, shouted Burns down. O'Hara defended his honesty and claimed that "I have preached that it is right to strike." Dr. Marie Equi, a physician and local leftist Progressive, made her first dramatic appearance in the press. Subsequently, due to her unconventionality and flair for the dramatic, she would eclipse Burns and the Schwabs in coverage. The Journal noted that she:

insisted on standing on a chair and speaking, though the others called her down and said she had not before and was not now doing the striking girls any good. Dr. Equi said she was willing to shed her blood on the picket line and exhibited a large bruise on her shoulder made, she said, by a policeman's club.

Although less dramatic than the confrontations provoked by Burns and Equi, a significant amount of testimony concerning wages and conditions was given at the conference. Mrs. Miller, an elderly striker, stated that "if it were not for the

11 Journal, July 11, 1913, p. 1; Oregonian, July 12, 1913, p. 1; Joumal, July 11, 1913, p. 1. 
assistance given by the despised agitators, I couldn't eat. They paid my rent, kept my table going, and paid for my sick boy." Mrs. M.E. Daniels, the first to proffer charges against Mary Schwab, claimed that "if we could only be left alone, we would all be one big happy family" and that the insults of the strikers "have only fostered in me a spirit of loyalty for the company, and I intend to remain here until I am told to go by the company." Both sides spoke at length, as in the previous conference, but again, little was solved.12

After the conference, Governor West issued a report summarizing the strikers demands and the action he would take regarding them. The primary demands, a nine-hour day at $\$ 1.50$ wage, he deemed insoluble except by legal action. West stated that the sanitary conditions of the plant and the establishment of rest, dressing, lunch, and sick rooms for the employees would be "taken up with the proper authorities" and "investigated and settled." He demanded that duplicate time slips "should be granted without question." This activist governor had begun his career as messenger for a Portland bank after leaving school, and had been raised in a working-class family which had been "left practically destitute" after the hotel they were living in burned down when West was a boy. Thus, no stranger to poverty, and elected as a populist Democratic reformer in a Republican state, it is clear that West sympathized with the strikers while remaining pragmatically conciliatory to business interests. As in the Coos County deportations, he framed his crusade in legal terms, thus providing a cloak of electoral safety. 13

12Journal, July 12, 1913, p. 1, 2; News, July 12, 1913, p. 1; Joumal, July 13, 1913, p. 4. 13 Oregonian, July 13, p. 2; Anonymous article, 'Oswald West' Vertical File, OHS. 
Now that the Industrial Welfare Commission, the Mayor, and the Governor had all failed to produce a satisfactory settlement, the strikers and their IWW and socialist organizers would have to force a resolution on their own. In light of the company's threat to close the evening following the conference if the disturbance was left unresolved, the Mayor decided to limit the number of pickets permissible in front of the plant to between ten and twelve. Indignant, the strikers marched back to the plant after the conference, rather than the vacant lot, and 150 participated in an evening protest. The result of this action, in defense of the right of all striking women to picket, again precipitated police action based on a reactive mayoral statement. At twenty past five in the evening, after attempting to clear the area before the plant unsuccessfully, six mounted police officers charged the crowd of pickets, injuring three women and causing a great deal of panic and confusion. Several arrests for disorderly conduct were also made. The Oregonian downplayed the story, and stressed the fruitlessness of continuing the strike, for the "plant has now replaced the strikers" and "the rush of the canning season ends this week." The Journal, however, reported that "men and women trampled eachother to get out of the way of the horses," clearly uneasy about the action of the police despite expressing antagonism toward the strike, and its IWW collaborators in particular. The News was indignant, comparing the charging policemen to 
Cossacks, and proclaiming a reign of legalized brutality against the innocent. Encouraged by the company's impending closure and publicity of police brutality, the Wobblies seized this opportunity the next day to demand that the J.M. Matchek Candy Company pay $\$ 1.50$ per nine-hour day to its women employees or risk a similar walkout. Although the threatened strike never occurred, the owner was sufficiently concerned to forward the letter he had received from IWW Secretary Fred Vollemen to the Mayor.14

As with the first arrests, police action once again transformed the conflict. Settlement of the strike demands immediately became subsidiary to establishing the right to publicize plant conditions and to allow all strikers to picket. The first challenge would come several days later, following the inconclusive trial on July 15 of Mary Schwab on four counts of "being disorderly and using abusive language" in a tense courtroom packed with supporters. Although several plant employees testified that Schwab had verbally abused them, she responded that she "had never used such language toward anyone." After a day of hearing the case, the jury failed to reach a verdict. It was revealed during the trial that she was a native of Russia, and that her husband Rudolph was a paid organizer for the IWW, and the son of Michael Schwab, one of the anarchist martyrs of Haymarket Square.15

14Oregonian, July 14, 1913, p. 2; Journal, July 13, 1913, p. 1; Oregonian, July 14, 1913, p. 2; Journal, July 13, 1913, p. 1; News, July 14, 1913, p. 1; Fred Vollemen, letter to J.M. Matchek, July 13, 1913, MSC, SPARC.

15Joumal, July 15, 1913, p. 2; Oregonian, July 16, 1913, p. 12; The 'Haymarket Affair' was a violent incident supposedly directed by anarchists against police authoirty during a public protest connected to a local strike. The resulting climate of public fear caused the scapegoating of eight individuals with anarchist symapthies whose connection to the incident was only tenuous. One committed suicide, four were hung, and three (including Schwab's father) were imprisoned. 
That evening, after the inconclusive trial, a four day free speech battle began between strikers and police. A street meeting downtown drew a large crowd and police presence to listen to speeches. This meeting marked the first involvement of County Sheriff Tom Word in local peacekeeping regarding the strike. While Burns was addressing the crowd, he reportedly ranted that "we'll fly the Socialist flag over one end of Tom Word's marble palace, the red flag of anarchy over the other end, and the IWW flag in the center." Immediately afterward, Burns was pulled off of the soap box from which he was speaking by a deputy sheriff in front of a crowd of several hundred. Following an established Wobbly technique, Rudolph Schwab then mounted the soap box to continue Burns's speech and follow him to jail. This time, the Sheriff himself and five deputies pulled down the speaker. Schwab was followed by one of the strikers, Mrs. O'Connor, who was pulled down by a deputy and followed by seven more speakers who were all arrested, one after the other. During the arrests, reinforcements from the police station arrived to clear the streets. The patrol wagon with its ten prisoners left for the county jail to book them on charges of disturbing the peace and using "profane and indecent language."16

A large portion of the crowd went in search of the prisoners, mistakenly setting off for police headquarters before re-routing to the jail. The Oregonian, now captivated by the dramatic Dr. Equi, claimed that she led the crowd to its destination and stormed in, punching a patrolman and night watchman in the face before being thrown "out onto the sidewalk where she landed on all fours." This event is impossible to verify, but seems an invention. Equi's 
primary purpose in proceeding to the jail was to secure the release of Mrs. $\mathrm{O}^{\prime}$ Connor, which she succeeded in doing, and to protest the behavior of the arresting officers. She claimed that she had been struck by an officer while trying to reach Mrs. O'Connor following her arrest, and displayed her bruises to officers at the jail. The nine remaining detainees were placed with the rest of the prison population initially, but were moved the next morning to a private cell on the top floor "as they insisted on breaking jail discipline by singing their socialistic songs," a traditional Wobbly tactic. Rudolph Schwab was kept in a private cell because he was "considered one of the chief troublemakers." It is unclear what sort of treatment the strikers received in jail, but if that of Tom Burns is indicative, they were handled quite roughly. "I was beaten in the face and kicked. I was slugged in the kidneys a dozen times while being taken to jail," he told the News. 17

The explosive events of the evening of July 15 threatened to transform a local conflict into a regional one. The strikers responded by holding a protest meeting outside the cannery during which three participants were arrested. The Journal claimed that 100 IWWs were coming north from San Francisco to help local agitators challenge the Mayor's new street speaking policy. Reportedly, they were working as railroad laborers to get as far as southern 
Oregon, and would then "beat their way north." In an attempt to avert fears of invasion, Sheriff Word claimed that "if necessary, we will make Kelly Butte a 'bull pen' and take care of 500 agitators there. This matter has got to be put to a stop quick, and we intend to do it." However, despite claims by the Oregonian that municipal and county authorities were cooperating closely, the Mayor exhibited the same thinly veiled antagonism toward the Sheriff's interference as he had to that of the Governor. Albee stated that:

as regards the arrests last night, all, or nearly all, the men were arrested by Sheriff Word, and he was acting on his own initiative. There was positively no understanding between the sheriff's office and the city's police authorities, although the police had orders to act if it became necessary.

Yet, only the News reported this portion of the Mayor's statement. The public perception that there was indeed close cooperation between municipal and county authorities quickly took hold, evidenced by its consistent recurrence in both newspaper reports and letters of congratulations to the mayor for his stand. H.J. Blessing, manager of Blessing Granite Company, wrote to Albee that "your work in harmony with the Sheriff's Office, especially appeals to me, as the former Administration was in constant conflict with the Sheriff and therefore accomplished nothing in a way of dealing with the vicious Element of the City."18

Once again, the Mayor made a reactive policy shift toward the strike in light of the escalation initiated by the Sheriff. Although he had promised to protect free speech, Albee announced on July 16 that all street meetings other 
than religious ones would be held only on the centrally located Plaza block, a public space across from the downtown courthouse. He warned that even this space would be denied to speakers if another riotous incident occurred. This rather moderate reaction, however, was reported as a "war to the finish upon the Industrial Workers of the World ... declared by Sheriff Word, Mayor Albee, and Chief of Police Clark." The statements supposedly made by Tom Burns, reported by the Oregonian as the cause of his arrest, appear to be as fabricated as the concerted anti-Wobbly war launched by municipal and county authorities. Burns was not known to be ideologically orthodox, making his threat to put the flags of three distinct philosophies (socialism, anarchism, and syndicalism) on top of 'Tom Word's' courthouse (who had previously not been involved in the strike) rather out of character. Steward Holbrook, a friend of Tom Burns, remembered that he "usually described himself as a Socialist. The label is not quite accurate. He was more the eclectic." In addition to a denial by the News that the inflammatory statement had been uttered, it seems unlikely that Rudolph Schwab would have been singled out as the chief instigator among those arrested if Burns had voiced such a threat. Schwab, although more formally affiliated with the Wobblies, was junior to Burns on the strike committee and did not instigate a string of ten arrests. The Journal actually attributed a variation of Burns's supposed remarks to another speaker entirely! Clearly, the mainstream press processed the events of the previous evening to make this conflict fit the mold of previous Wobbly struggles. 19

19 Oregonian, July 16, 1913, p. 1; Journal, July 16, 1913, p. 1; Oregonian, July 16, p. 1; Stewart Holbrook, "Some Notes on an Old School Radical," The Call Number 20 (Fall 1958) 4; News, July 16, 1913, p. 1; Joumal, July 16, 1913, p. 7. 
Although the threatened 100 Wobblies from San Francisco never emerged, the mainstream press, goaded by the strikers themselves, stressed the imminence of an invasion by radical agitators. A meeting in the Plaza square on July 16 drew a huge crowd (estimated at 2,500 by the Journal) to witness the spectacle that had caused ten arrests the previous evening. The crowd had been expecting the strikers to return to the downtown corner they had previously used, but they merely marched by this spot and told the expectant crowd to go to the Plaza block. Although several individuals attempted to start their own meetings outside the proscribed area, they were prevented from doing so by the police, and the evening saw little tumult. The speeches "were well within the bounds prescribed by the city officials." However, the strikers were clearly in a weak position by the evening of July 16 with all three members of the strike committee in jail. Schwab and Burns had been arrested the previous evening, and McDonald had been arrested at the plant that morning. There were no longer any unexplored channels through which to negotiate. In addition, the arrests of that morning and the previous evening had demonstrated that the downtown streets and the plant itself were clearly off limits. In desperation, the speakers threatened repeatedly on the evening of the July 16 to flood the town with reinforcements for their campaign if their demands were not met.20

The reaction of police authorities was immediate and exhibited a genuine fear of invasion. On July 17, the Journal reported that "steps are now being taken by the authorities to drive all vagrants from the north end." Shortly

20 Oregonian, July 17, 1913, p. 12; Joumal, July 17, 1913, p. 11; Oregonian, July 17, 1913, p. 12; Joumal, July 17, 1913, p. 11. 
before noon, ominously, three IWW delegates went to the Mayor's office "to clarify the street speaking situation." That evening the climax of the strike took place on a downtown street corner forbidden to speakers. Insisting on presenting their case, and without the IWW and socialist strike leaders, a delegation of striking women organized their own protest aimed at informing the public of the facts concerning the strike. Ten minutes after the group of women arrived on the corner, accompanied by Mary Schwab and Dr. Marie Equi, county and municipal authorities attempted to clear the crowd of 3,000 that had gathered to hear them speak. Complete chaos ensued and many bystanders were clubbed while trying to move out of the way of police. One witness told the News that "mounted police rode into crowds of men, women, and children and blackjacked them piteously without warning." The Journal attempted to lend a sense of inevitability to the police beatings with the explanation that "soon after the disturbance started it was impossible to distinguish reputable citizens from the agitators and this was the cause of many being struck by the police." The paper clearly ignored the fact that the 'agitators' in question were an orderly group of women strikers who were attempting to set up a speaking stand on a forbidden corner. The officers were using violence to disperse the crowd, not subdue the speakers. The police were obviously ready for a strong show of force, having been warned by that day's edition of the News that 100 striking women would present their case that evening downtown. Word was accompanied by thirty deputies, and two police sergeants with twelve men were present. Immediately after the officers began clearing the crowd, two police captains with forty-two men, a sergeant with 
twelve men, and a squad of nine mounted police arrived. By the time the police reached the group of women, only seventeen remained. All were arrested, although they had not even finished setting up their speaking stand, and taken to police headquarters to be processed. While being taken from the station to the jail, Dr. Equi stabbed a patrolman in the wrist with a hatpin. She was charged with disorderly conduct, inciting a riot, carrying a concealed weapon, and assault with a dangerous weapon. Mary Schwab was charged with inciting a riot and disorderly conduct. Three other women were charged with inciting riot. The rest were charged with disorderly conduct. All were released on bail except Equi, Schwab, and $O^{\prime}$ Connor. 21

On the morning following her arrest, three friends of Dr. Equi called upon Sheriff Word and promised to remove her from the state if she were released and charges dropped. After being taken to the train station and discovering she was to be sent to San Francisco, Equi refused to leave and was returned to the county jail. "Honestly, now, did anyone imagine for a moment that I was a quitter? I'm here to see this thing through and I won't run." The Sheriff claimed that if she was judged to be sane he would press the charges. Equi refused to post bail and also refused to eat prison food (she had her own brought in). The Oregonian explained her behavior by continuing to portray Equi as dangerously insane. The previous evening she had supposedly "swung a wicked looking section of gaspipe" (that it was part of the speaking stand she was setting up was ignored in the report) "and screamed that she would kill p. 1; Joumal, July 18, 1913, p. 6; News, July 17, 1913, p. 1; Oregonian, July 18, 1913, p. 1, 5; Joumal, July 18,1913, p. 6 . 
anyone who tried to make her stop talking" (although no speaking had yet occurred). Supposedly, the afternoon prior to the street meeting, she had told an Oregonian reporter that she intended to "prepare a virus in which she would dip a pin, a stab from which would cause a slow, lingering death." The survival of Patrolman Evans attests to the falsity of this statement.22

On July 18, the Oregonian reported that "indications that white slavers, working boldly under the guise of Industrial Workers of the World and their sympathizers have established a recruiting station among the young girls in the IWW picket line." The paper also asserted that "IWW agitators, many of them rough men from the North End sections, mingle freely with these girls, talk with them, ... and in general affect close intimacy." Sergeant Harms claimed that "he never saw conditions more made to order for leading young girls astray than those that exist before the fruit company." A "flashily dressed woman" was seen mingling with the girls, and attempting to lure them away. Yet at no time was evidence presented that sexual immorality of any kind had been caused by the strike coalition of men and women. Mary Schwab told the News that the story was a complete falsehood and that the supposedly 'flashily dressed woman' was a striker who wore a black velvet dress she had bought five years before and now "has a few patches on it, and is pretty well worn." 23 That same day, Chief Clark and Sheriff Word "issued orders ... to arrest all I.W.W. leaders their officers encounter and charge them with vagrancy." The News reported a few days later that this policy had resulted in a number of

22Journal, July 19, 1913, p. 1, 5; Oregonian, July 18, p. 1.

23Oregonian, July 18, 1913, p. 5; News, July 19, 1913, p. 1. 
arrests of individuals completely unconnected with the Wobblies. The paper asserted that all those out of work, or with less than $\$ 10$ cash, or who could be goaded into making disparaging comments about local authorities, were arrested. John Jeffreys, attorney to the strikers, suggested that "workingmen ... keep their own counsel and refuse to talk to these chaps until this epidemic of arresting inoffensive people is at an end." The records of Detectives Goltz and Royle for the July 18 find them "around town looking for idlers and vagrants also vagging I.W.W.'s." The Journal reported that Immigration Inspector Barbour and Assistant City Attorney Stadter would also be pursuing the possibility of deporting alien radicals involved in the strike. Tom Burns, having just been sentenced to forty days on the rock pile, was discovered by Sheriff Word to be a British national and possible army deserter who potentially could be deported.24

Despite this thorough campaign to prevent a protest response to the arrests of the previous evening, a crowd of 1,000 gathered at the Plaza block on July 18 to listen to Isaac McBride (son-in-law of U.S. Senator Harry Lane), Mary Schwab, and socialist George Reece. The previous day, anxious to protect the monument to the Second Oregon on the Plaza block, the United Spanish War Veterans asked Sheriff Word to swear them in as deputies and he promised he would do so if the situation continued to escalate. Regardless, the veterans decided to deploy a presence of sixteen to protect the monument "to see that it was not desecrated." The veterans did not see action, but during the third

24Joumal, July 18, 1913, p. 1; News, July 21, 1913, p. 1; July 23, 1913, p. 1; Detectives Goltz and Royle, July 18, Investigative Record Books, SPARC; Joumal, July 18, 1913, p. 1; Oregonian, July 19, 1913, p. 4. 
speaker's talk, Sheriff Word moved in and arrested him. The manner of the arrest caused quite a disturbance, precipitating other arrests and a forceful attempt to halt the expansion of the crowd into surrounding streets. James Gregory, a bystander, was seriously wounded by Sheriff Word, who hit him in the face with a blunt object after the man had fallen to the ground. His cheek was gashed open and several of his teeth loosened. Although the Oregonian reported that he had attacked the Sheriff, the News rejected this report after contacting his attorney to obtain the full story. A man who had witnessed the unprovoked attack complained immediately to the Sheriff and was arrested, as was Gregory. The following evening, an uneventful meeting was held on the Plaza block during which Isaac McBride again spoke. Presumably, if the Sheriff had not begun mailing arrests the previous evening, the evening of July 18 would have progressed to a peaceful conclusion much as that of July 19 did.25

On July 20, the Journal reported confidently that "with most of the agitators in jail, the disturbances ... seem to be nearly at an end." Sheriff Word shared the paper's optimism, stating that "I do not believe that the agitators will continue to make trouble, as they seem to realize its futility." However, the 'vagging' campaign continued with twenty-eight more men taken into custody.

25 Oregonian, July 19, 1913, p. 1; July 18, 1913, p. 1; July 19, 1913, p. 1; News, July 19, 1913 , p. 1; Oregonian, July 19, p. 1; News, July 19, p. 1; Journal, July 20, 1913, p. 1. 
In addition, on July 23 , Albee attempted to effect his only proactive policy shift of the entire affair by introducing a measure into a city commission meeting titled "an ordinance making it unlawful to insult or degrade the flag of the United States or to incite disorder within the City of Portland, prescribing penalties for violations thereof, and declaring an emergency." Commissioner Brewster thought the measure too strong, and referred it back to the Mayor for further consideration. It was never resubmitted. Brewster told the press that "true respect for the flag cannot be brought about by law and any attempt to force a feeling which does not exist will produce more bitter feeling and greater hostility." The Journal editorialized that "nobody challenges the advisability of passing a restrictive measure," but that the idea of criminalizing comments critical of the government was against the spirit of the American Revolution and would have hindered the exposure of corruption in past municipal administrations. Infraction of the ordinance carried the rather extreme penalty of one year in prison and a $\$ 500$ fine. Albee, who appeared quite moderate throughout the conflict, had suddenly positioned himself quite precariously. 26

A Free Speech League was formed in the wake of a meeting in the Gypsy Smith Tabernacle on July 26 , attended by 5,000 , to protest the Mayor's ordinance and the violent behavior of Sheriff Word, and to instigate a recall movement to remove both officials. Commissioner Brewster was commended for his stand against the Mayor. Another meeting in the same location was held the following weekend, on August 2, but attendance declined. Although the

26Journal, July 20, 1913, p. 1, 5; City Council Record for July 23, 1913, Council Proceedings, SPARC; Oregonian, July 24, 1913, p. 16; Journal, July 24, 1913, p. 8; Oregonian, July 23, 1913, p. 9 . 
News attempted to portray solid support for the recall movements, one of the most important speakers, Seneca Fouts, wrote Albee a letter after reading in the Oregonian, to his dismay, that he had called for the Mayor's removal. Fouts portrayed his talk concerning 'free speech' as one focused on the reciprocal duties "I considered the citizens owed to the country and our governmental authorities owed to the people." He protested that his language was not indecent or unpatriotic. He assured the Mayor that he did not support a recall movement, although the policy he had followed during the strike was "illadvised." 27

Although it is unclear at what point picketing at the cannery ceased, the Mayor reported that "there is no longer even the pretense of a strike at the plant" after visiting the site on July 18, the morning after Dr. Equi and the women strikers were arrested downtown. However, the News did not concede the strike until August 1, the day Albee announced his new street speaking policy. The Mayor now insisted that the congested area of the downtown and all street car intersections be kept free of public meetings in order to keep the peace and allow free flow of traffic. He also had just made a statement proclaiming his proposed municipal ordinance to be redundant, for there was already a state law in place to prevent "the use of language tending to incite disrespect for the American flag." The matter appeared settled, for on August 6, at a rather small meeting on the Plaza block, Rudolph Schwab was arrested by Sheriff Word. No protest followed his arrest, although thirty "free speech

27News, July 29, 1913, p. 1; July 28, 1913, p. 1; August 4, 1913, p. 1; Seneca Fouts, letter to H.R. Albee, August 4, 1913, MSC, SPARC. 
prisoners" had recently been released by City Attorney LaRoche and the News reported that only three convictions had been obtained from 100 arrests and those three were appealing. 28

Yet radical street speakers did not disappear. On October 2, the Mayor received a letter from Benjamin Brick, a Juvenile Probation Officer, who lamented the ease with which crowds gathered downtown in anticipation of 'free speech' agitators despite a significant police presence. Why could the police not clear the crowds before the speakers arrived, he queried, thus halting a meeting before it could begin? The Mayor replied that "the orders have been given to do as requested in your letter; that is, keep the street clear before the need occurs, but the fact is ... that five seconds appears to be enough to draw a large crowd at a given point during these disturbances." The battle for 'free speech' appeared to be a conflict neither side could win.29

28 Oregonian, July 19, 1913, p. 8; News, August 1, 1913, p. 1; Joumal, August 1, 1913, p. 1; Oregomian, July 31, 1913, p. 11; August 6, 1913, p. 4; News, August 1, 1913, p. 1.

${ }^{29}$ Benjamin Brick, letter to H.R. Albee, October 2, 1913, MSC, SPARC; H.R. Albee, letter to Benjamin Brick, November 6, 1913, MSC, SPARC. 
Conclusion:

Cultural Sources of the Conflict 
In order to form a more complete understanding of opposition to the IWW in western towns, a synthesis reflecting the typically diverse coalitions arrayed against them is needed. Robert Johnston's recent dissertation on the lower middle-class in Progressive era Portland described a shared political vision among working and middle-class activists. Johnston's work drew upon the findings of Herbert Gutman, who uncovered extensive cooperation between working and middle-class individuals in the late nineteenth century to battle corporate enterprise foreign to their communities. Yet, Johnston argued, "what could have become one of the most significant problems in labor history's intellectual agenda" was completely ignored by the many scholars who have built upon Gutman's invaluable work. A path forward, Johnston suggested, necessitates an "integrated history of class relations" that recounts middle-class activism in an inter-class context, rather than continuing to engage in "the arbitrary separation of the histories of the working class and the middle class." The events and language of the Oregon Packing Company strike can be utilized to build upon this idea. 1

One significant aspect of the strike is the total absence of local affiliates of the AFL and coverage in the newspaper targeted to their membership, the Portland Labor Press. Although the Wobblies and radical socialists would surely have repudiated AFL assistance, the striking women themselves (aided by the Daily News) issued a plea for help to every labor union in the city on July 8 , the day that the company brought its case to the Mayor with the support of the East

1 Robert D. Johnston, "Middle-Class Political Ideology in a Corporate Society: The Persistence of Small-Propertied Radicalism in Portland, Oregon, 1883-1926," Ph.D. dissertation, Rutgers University, 1993, 25-26. 
Side Business Men's Association. The strikers, seeking similarly solid backing, received none. This result should have been unsurprising, for the Wobblies had brought the enmity of skilled labor in Portland upon themselves since their first appearance there in 1907. The IWW lumber mill strike that spring closed almost every operation in the city in under a week and brought over 1,800 men into Portland Local 319. The union demanded a nine-hour day at $\$ 2.50$ per man. These tactics bore strong resemblance to that of any national union, and in themselves did not depart significantly from the AFL tradition.2

The cooperation between the AFL Central Labor Council and the mill owners to successfully defeat the Wobbly strike could be ascribed to an economic struggle between the two groups, capital and skilled labor, to establish a balance of power in the Pacific Northwest. The lumber industry was unorganized, yet dominated the regional economy. Dubofsky indicated that the Portland strike was the first major attempt of an outside organization to broach this detente, and initiated a discernable shift in industrial relations in the region. He cited Will Ames of the Puget Mill Company asserting after the strike that it would "be well for the company to do everything in its power to have things pleasant for the men ... The days of the cabins and the man with the blankets is over." Organized labor and industry were adamant about making an immediate stand against the Wobblies, even if a certain amount of internal compromise was required. 3

Yet the AFL was not cooperating with the mill owners merely to repel an

2Daily News, July 8, 1913, p. 1; Melvyn Dubofsky, We Shall Be All: A History of the Industrial Worker of the World (Urbana: University of Illinois Press, 1988) 129.

3Dubofsky, 130-131. 
invader into its sphere of economic hegemony. Although Dubofsky emphasized that strike leaders "mentioned revolution only as a future possibility, never as an imminent prospect," ideology was hardly invisible or irrelevant in the continuing antagonism between Wobblies and the labor establishment in Portland. The very concept of syndicalism was as abhorrent to mainstream organized labor as it was to Portland lumber barons. The Portland Labor Press praised Brooks's vitriolic indictment of syndicalism in a book review published several days into the Oregon Packing Company strike. The Labor Press raged that "syndicalism is a reversion to primitive, barbaric methods" and "has flourished most where there is least knowledge of what Americanism is." In the wake of the strike, the Independent Longshoreman's Association was desperate to quell rumors of radical sympathies and held a special meeting to pass a unanimous resolution condemning the IWW, repudiating its philosophy and methods, and barring any Wobbly from membership. Their oath of loyalty was amended to reflect this resolution, which was delivered to the Mayor. In late August, the Mayor received a similar resolution from the Pleasant Valley Grange. The organization affirmed that it was "living today under the most liberal and enlightened government ever enjoyed by a people" and that the Wobblies were rightly being repressed by municipal and county authorities because they had unjustly degraded the Constitution and the flag, which the members of the Grange considered to be "the insignia of ideal liberty." 4

There is ample evidence that during the conflict individuals affiliated

4Dubofsky, 130; Portland Labor Press, June 30, 1913, p. 1; A.F. Schaab, letter to H.R. Albee, August 14, 1913, Mayor's Subject Correspondence, Stanley Parr Archives and Records Center, Portland, Oregon; Pleasant Valley Items, August 23, 1913, MSC, SPARC. 
with the labor or socialist mainstream overtly avoided implication with the Wobblies. On July 18 , when the free speech conflict that emerged out of the strike was at its peak, a committee representing a local organization of moderate socialists called upon the Mayor. The group wanted to hold a meeting downtown, and decided to go through formal channels to obtain permission. The Mayor denied their request to use the streets, but "appealed to them as citizens not do so and to aid the police in enforcing order." The purpose of their proposed meeting is unclear, but the most prominent among them, Isaac McBride, was the only speaker at a peaceful meeting on the Plaza block during the evening of July 19, in which "he dwelt at some length upon the foolishness of mob rule and urged his auditors not to take part in any riot which might start following an arrest." On July 22 , the Oregonian reported that Sheriff Word had received numerous requests from workers to be sworn in as deputies, all of them claiming that "they regard the Industrial Workers of the World as enemies of organized labor." On July 30, Mayor Albee told the press that he was "much pleased with the wisdom displayed by labor," for "thus far the sober, thinking laboring men and women, both organized and unorganized, have stood by right principles and have refused to be misled." 5

The commentary of the Labor Press reiterates the Mayor's perception of the position of mainstream labor regarding the strike. "If starvation haunts the girls and women in Portland while they work from early morning to late at night," the paper editorialized, "now is not the time to play cheap politics and

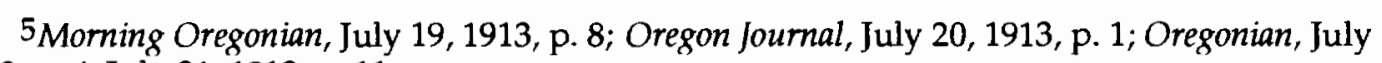
22, 1913, p. 4; July 31, 1913, p. 11. 
fuss on the street." The Labor Press seemed to be gloating over the impending failure of Wobbly leadership of the strike, and caricatured their tactics as childish and irresponsible. References to "schoolboy pyrotechnics" and "insane quarrelling over shadows" and their result, introducing "desolation and disaster into the life of the community," reveal an antagonism toward the IWW deeper than tactical divisions. Although the labor establishment had neglected to aid the strikers, the Labor Press became indignant over the fact that "people seem to have forgotten the cries for food which went up when girls and women were ready to accept charity to prevent death from starvation." On July 28 , the paper endorsed Mayor Albee's opinion that picketing was fruitless and that the strikers would be better off negotiating through the Industrial Welfare Commission. 6

The labor establishment, however, was not merely kowtowing to municipal authorities and the business community to protect their growing influence and membership. A Progressivist ethos crossed traditional class lines and often made these groups allies in reform, even if motivations were disparate. Warren Blankenship has argued that support for Portland's new municipal charter crossed class lines, in contradiction to Samuel Hays, who supposed that the new system was championed by the urban elite. Blankenship maintained that although it is possible that the Progressive Party was used as a vehicle by an elite group that sought "to gain direct control over municipal government so that they could exercise their political control more effectively," Mayor Albee was not merely a tool of business interests. He noted that the 
founders had mainly remained the leaders of the local Progressive political faction and could not "be construed by any stretch of the imagination to be representing an elite if that term is meant to include only the upper stratum of society in the social and economic sphere." It is crucial, Blankenship adds, that "it was they who sought Albee's candidacy, not he their support." The umbrella of Progressive politics was wide indeed.7

Progressivism was more important as an idea than a political label. Although Albee won office in 1913, he garnered only 32\% of the vote. The opponent he defeated in the primary ran as an independent, bringing the Progressive vote to $44 \%$. Although certainly not a mandate, the vote is significant if one considers that less than $5 \%$ of voters were actually registered as Progressives. The appeal of the party as a temporary vehicle to establish honest government under the new charter and initiate social reform was both diverse and substantial. The Spectator opposed Albee's candidacy because it claimed he had the full support of two of its strongest opponents: the conservative Oregonian newspaper and the labor unions. As incongruous as this alliance may seem, it indicates the extent of shared values and genuine desire for rational cooperation between these two economic factions. The Progressive Business Men's Club held an informal reception at the Oregon Hotel on December 16, 1913 in conjunction with the Multnomah Bar Association to give the two constituencies a chance to interact. Significantly, the two organizations invited all leading labor leaders to the event, so that members of all three

7Warren M. Blankenship, "Progressives and the Progressive Party in Oregon, 19061916," Ph.D. dissertation, University of Oregon, 1966, 236-238. 
groups "may become better acquainted one with the other." The hosts "hoped that the result of the gathering" would "be a closer relationship, a wider acquaintance and a better feeling between these men in this community." The Mayor was invited in order to lend "strength to the ameliorating and welding influence that we hope will be exerted." 8

The characterization of the AFL in Wobbly scholarship as sycophantic toward capital has grown out of a lack of emphasis on cultural values in economic conflict. Portland's business and labor establishments were actively formulating a balance of power, but both were clearly checked by community standards and shared values. In his study of Progressive era San Francisco organized labor, Michael Kazin noted that "proprietors of locally owned, longexisting firms knew that labor's aims were popular in the general community." Significantly, Kazin emphasized that although businessmen often battled particular unions, they "usually defended the principle of unionism itself." Without a common cultural language, the two economic groups would have achieved a much more limited understanding of appropriate means of conflict resolution. The similarity of the language of rejection of IWW ideology and methods by both factions strongly indicates that the Wobblies had repudiated the cultural symbols, the 'Americanism,' used in these negotiations. The assertion that the AFL was elitist is substantial, but the idea that the union was sycophantic because it adhered to community standards of speech and behavior and attempted to form stable relationships with business interests by

8Blankenship, 245, 240, 243; Arthur Langguth, letter to H.R. Albee, December 10, 1913, MSC, SPARC. 
emphasizing cultural bonds between them is not substantiable. 9

Since its very inception, the IWW served as a unifying idea among many labor radicals, including not a few who were unaffiliated with the organization but sympathetic to its aims. Not unlike the Progressivism of their opponents, a Wobbly 'sensibility' provided these individuals with a common language to express these aims and the means of reaching them. Perhaps the broadest and most resilient coalition of radicals that the IWW fostered during the course of a single action was, ironically, one that fought exclusively for civil liberties and ignored working-class organization. Yet, the San Diego 'free speech fight' of 1911-12 marked "the most brutal and protracted anti-IWW activity" of the prewar years. This conflict was, in many ways, the climax of cultural tension between Wobblies and Progressives. The lack of any strike activity within the 'free speech' struggle has allowed admiring historians of the Wobblies to claim it as a costly mistake from which much was learned and a desire to concentrate solely on organization reaffirmed. Detractors gained a defining example of the IWW engaging in agitation for its own sake while neglecting unionism, and claimed San Diego representative of Wobbly means and ends. 10

\section{Johnston, 121.}

10Narrative of San Diego conflict found in John Clendenin Townsend, Running the Gauntlet: Cultural Sources of Violence Against the I.W.W. (New York: Garland Publishing, 1986) Chapters 2 \& 3; Townsend, 17; The work of Philip Foner and Melvyn Dubofsky is representative of the first group of historians, and that of Robert Tyler is indicative of the latter. 
The fight in Portland during the following year reveals the simplicity of both notions. Local adherents of the IWW pushed the Oregon Packing Company to recognize the claims of its striking workers and hoped to unionize the women in the cannery. The letter from Fred Vollemen, IWW Secretary in Portland, to the J.M. Matchek Candy Company also makes clear that the Wobblies hoped to unionize women in other local industrial concerns. They clearly realized the importance of public protest as a means to organization, as the methodology of the strike clearly indicates. Portland Wobblies sought to raise a common consciousness among these women, inspire protest, and offer organization. It would be simplistic to assume these actions were not replicated elsewhere, and that because failure tended to mark them they were not in earnest. It is similarly unhelpful to ignore the interconnectedness of organization drives and civil liberties struggles in Wobbly conflict. Even after the intensity of the conflict had subsided, Rudolph Schwab, a paid IWW organizer, was arrested while promoting Portland's newly formed Free Speech League. San Diego did not spur an abandonment of the 'free speech' tactic, or of coalition forming to obtain that end. However, the significance of that conflict for western Wobblies and Progressives should not be diminished. During the Portland struggle, the specter of San Diego loomed large. When the East Side Businessmen's Club approached the Mayor on July 8 for help in suppressing the strike, the Oregonian warned that interference might "stir up a hornet's nest like that which played havoc in San Diego recently." Whenever Wobblies threatened to flood the city with agitators and fill the jails, and whenever local authorities broke up street meetings and engaged in 'vagging,' 
the events of the previous year in San Diego seem to have functioned as a warning from each side to the other. 11

Much of the language used by members of the strike coalition did concentrate on aggressive invasion, and more than a few of the strike leaders were immigrants. The mainstream press concentrated heavily on these aspects of the strike. Tom Burns (English), Mary Schwab (Russian), and Henry Schoen (German) were all suspected of being in the country illegally. John Higham has found that Germans were one of three immigrant groups that dominated trade union leadership at the turn of the century, and although German-Americans comprised only $3.6 \%$ of Portland's population, the percentage of arrestees during the strike with German names was much higher. It is important to establish that antagonism toward these individuals did not arise from fear of immigrants, for over $40 \%$ of Portlanders in 1910 were foreign born or had immigrant parents. The idea of Wobblies and their sympathizers as invaders was much more important than the idea of them as foreign. During the conflict, ethnicity was only stressed in press reports when citizenship status was suspect. A perceived categorical rejection of American institutions and associated customs was much more important in engendering opposition to the Wobblies and their cohorts in prewar western towns than ethnic status. 12 Whether this rejection of cultural values among western laboring

11 News, June 28, 1913, p. 1; Fred Vollemen, letter to J.M. Matchek, July 13, 1913, MSC, SPARC; Oregonian, July 28, 1913, p. 7; July 9, 1913, p. 10.

12Oregonian, July 19, 1913, p. 4; Joumal, July 15, 1913, p. 2; July 16, 1913, p. 1; John Higham, Send These to Me: Immigrants in Urban America (Baltimore: Johns Hopkins University Press, 1984) 24; Stephen T. Janik, "Prosperity and the Pursuit of Order: Portland, Oregon during the Progressive Era, 1900-1913," B.A. (Hon.) thesis, Harvard College, 1969, 22-23; Paul G. Merriam, "The 'Other Portland': A Statistical Note on Foreign Born, 1860-1910" Oregon Historical Quarterly 80 (Fall 1979) 265. 
communities was real or manufactured, however, remains unclear. Dubofsky claimed that Wobbly opposition to capitalist values, symbols, and institutions was the organization's binding force. Yet Conlin found the union adept at compromise with municipal authorities, which surely would have required some degree of shared cultural framework with their opponents. The Portland conflict does indicate that there was a great deal of ambivalence among the strike coalition concerning rejection of outside intervention and espousal of extreme methods. Just after the peak of the free speech conflict, Dr. Marie Equi told the press that she "had hopes of getting a settlement but Burns and the authorities mixed too often." Burns had denounced the interference of the Industrial Welfare Commission, although the Journal reported that a group of strikers had requested their assistance. Yet he still led a group of women to the Mayor's office seeking help and assented to the conference proposed by the Governor. There is also evidence of protest by the strikers against the harangue launched by Equi during the latter attempt at compromise. The radical strike leaders, thus, were capable of shifting between antagonism and compromise rather easily. 13

The leaders were also guided by disparate motivations and ideological fluidity. Prior to the strike, Equi was what Burns would have called a 'parlor reformer' and was mainly concerned with mainstream Progressive issues, although she did have a reputation for pursuing them aggressively. On the very day the Oregon Packing Company strike began, Equi, in her capacity as

13Dubofsky, 148-151; Joseph Robert Conlin, Bread and Roses Too: Studies of the Wobblies (Westport, CT: Greenwood Publishing, 1969) 74-76; Jourmal, July 19, 1913, p. 5; News, July 4, 1913, p. 1; Journal, June 30, 1913, p. 2; July 8, 1913, p. 15; July 11, 1913, p. 1; July 12, 1913, p. 2. 
President of the Eight-Hour League, sent a letter of thanks to Mayor Albee for his contribution to the cause. Ironically, she sent "very best wishes for the success of your future work." It seems likely the irony was also apparent to Albee, for the letter was stamped received on July 12, by which time Equi had launched many epithets toward his administration most contradictory to the sentiments included in her letter. The Journal reported, after her arrest, that "friends of Dr. Equi are at a loss to account for the stand she has taken in regard to the Industrial Workers of the World and the strike on the east side." Nancy Krieger has asserted that "the events of the cannery strike fundamentally altered Equi's life. The strike radicalized Equi through exposing her to both police brutality and to the weaknesses of the politics of the Progressive Party." Equi did state, almost a year after the strike, that the Oregon Packing Company conflict had turned her away from the political process and led her to believe only in 'direct action.' 14

It should not be forgotten that the attachment of the striking women to the radical organizations and individuals assisting them was recent, formed for utilitarian reasons, and seemed to have only rudimentary formality. After most of their leaders were in jail, the strikers attempted to hold a street meeting without them on July 17 and seemed to have been followed by Dr. Equi, who was assumed to have led them. She told the press several days later that she had "advised the girls not to attempt to speak on the street the other night, but they would do it, so I went along." Yet, the Mayor had claimed that "the

${ }^{14}$ News, July 4, 1913, p. 1; Nancy Krieger, "Queen of the Bolsheviks: The Hidden History of Dr. Marie Equi" Radical America 17.5 (1983) 58; Marie Equi, letter to H.R. Albee, June 28, 1913, MSC, SPARC; Journal, July 19, 1913, p. 5; Krieger, 60. 
agitators ... persuaded some women strikers to appear at Sixth and Washington Streets." His attribution of responsibility for the meeting to radical leaders rather than women strikers is unsurprising. Ardis Cameron has asserted that local Progressives and Wobbly leaders alike, during the 1912 textiles walkout in Lawrence, Massachusetts, "refused to see women as active participants in the strike." A striker killed during a street meeting was held up by both factions as a "symbol for the victimization of the city's laboring women." Yet her work has uncovered a pivotal role for striking women independent of trade unions. “'Unorganized' by formal institutions, the threads of everyday life reinforced a sense of commonality among disparate members of the community, providing an effective counterweight to dissent organized from above." As Vincent DiGirolamo also discovered in his research on the women who participated in the Wheatland, California hoppickers strike, solidarity from shared experience as women and workers proved to be a more effective binding force than strict ethnic or ideological loyalties. 15

Yet Ann Schofield has asserted that the events and language of the Lawrence struggle also indicate that "inclusion of women in the One Big Union, at least during a major labor confrontation," was genuine. "The Wobblies acknowledged that women had unique problems and they responded with special organizers." Schofield indicated that the IWW was preoccupied with prostitution, but always faulted capitalism and never the prostitute. Her

15Joumal, July 19, 1913, p. 5; H.R. Albee, letter to Clarence L. Reames, September 19, 1913, MSC, SPARC; Ardis Cameron, Radicals of the Worst Sort: Laboring Women in Lawrence, Massachusetts, 1860-1912 (Urbana: University of Illinois Press, 1993) 176, 140; Vincent DiGirolamo, "The Women of Wheatland: Female Consciousness and the 1913 Wheatland Hop Strike" Labor History 34 (Spring 1993). 
research showed that Wobbly cartoons and literature on the subject stressed the need for solidarity between the hobo and the prostitute, both victims of a ruthless capitalist society. This view of economic oppression as the major causal factor of contemporary prostitution stood in stark contrast to that of Father O'Hara, Chairman of the Industrial Welfare Commission of Oregon. O'Hara refused to use the specter of prostitution to rally support for the minimum wage movement, condemning such a tactic as insulting to the women he sought to uplift. Yet evidence of the strike coalition's reliance on this tactic to achieve their economic aims is rife during the Portland conflict. Equally clear is the high degree of antagonism it aroused among municipal authorities. Mary Schwab was alleged to have called a cannery worker who refused to join the strike a 'white slaver,' and although a conviction was not obtained, her trial for use of abusive language was the most publicized of the conflict. From the beginning of the strike signs appeared linking low wages to prostitution. Several days into the walkout, a striker was seen carrying a sign reading "forty cents a day is what makes prostitutes, girls demand a living wage." A speaker collecting money to build a strike fund proclaimed that "many of these girls and women are self-supporting, and such conditions make for white slavery." When the strikers descended upon the Mayor's office on July 8 , one carried a sign that read "to Hell with White Slavery and \$6 per week." The Mayor objected, and later told the press that "signs such as this are certainly not decent and will not be permitted." 16

16Ann Schofield, "Rebel Girls and Union Maids: The Woman Question in the Journals of the AFL. and IWW, 1905-1920" Feminist Studies 9 (Summer 1983) 348-350; Edwin V. O'Hara, A Living Wage by Legislation: The Oregon Experience (Salem, OR: State Printing Dept., 1916) xixxx; Oregonian, July 17, 1913, p. 12; Joumal, June 30, 1913, p. 2; July 11, 1913, p. 1. 
Although there seems to have been coalition-wide consensus on this issue, the absence among strikers of radical ideology either on banners or in reported speech reveals the extent of their independence from the radical organizations and individuals that assisted and organized their strike effort. Signs such as: "don't be a scab, we will feed and take care of you," and "we are your friends, let us help you" were typical of those that were used during the conflict. They indicate a solidarity built on trust through common experience, not ideology. Although Mary Schwab claimed that "we have made a Socialist out of every policeman on duty over there," there seems to be little evidence that they had even made socialists of the strikers. The ideological independence of the strikers, and the radicals' tolerance of it is highly significant in establishing the fluidity of power relationships within the coalition. That the ideological radicals themselves often wavered between compromise and intransigence and evinced disparate motivations further muddies any analysis of the binding force within the group. 17

There is no indication that the striking women rejected American institutions or community standards of morality and it is also unclear if the radical strike leaders consistently did so. Thomas Cooley was arrested on the evening of July 15 for supposedly "making disrespectful statements of ... organized government," clearly implying anarchic sympathies. However, Cooley claimed in court "that he meant no disrespect, merely making a remark that a laboring man has no rights." Henry Schoen, also arrested that evening, was "closely questioned" by Judge Stevenson to see "if he believed in direct

17News, June 28, 1913, p. 1; July 21, 1913, p. 4; Oregonian, July 13, 1913, p. 2. 
action, or violence." He denied espousing these ideas. Tom Burns was also accused of making anarchic and violent statements that evening, though the comments attributed to him by the Oregonian were assigned to Ramsley by the Journal and the utterance of any such statements was denied by the News and their manufacture blamed on the necessity for the authorities to excuse otherwise unjustifiable arrests. 18

If Wobblies and their allies were neither adept at compromise with authority or unanimous in their opposition to it, the question of what did bind them together must arise. In the Portland conflict, agreement concerning the clearly oppressive nature of Oregon Packing Company conditions and work environments at other industrial establishments employing women was the only major cohesive influence. However, some sort of common cultural language was needed to ensure the agreement of all activists and strikers that the brand of reform currently championed by the state through the Industrial Welfare Commission, if proven inadequate, should be superseded. The immediate need to alleviate the misery of women in industrial life and eliminate expoititave prostitution resulting from it seems unquestioned by all members of the coalition. They communicated this understanding through a radical 'sensibility,' an extension of Salerno's notion of a Wobbly 'sensibility' that "gave passage to the social networks that defined its community" but was not predicated on a particular ideology. In order for the coalition to survive, all strikers and organizers would have had to agree that traditional methods of

18 Journal, July 16, 1913, p. 1; Oregonian, July 16, 1913, p. 1; Journal, July 16, 1913, p. 7; News, July 16, 1913, p. 1. 
industrial conflict resolution needed to be disregarded in at least some circumstances and possibly replaced with alternatives antithetical to Progressive cultural norms. Without this implicit understanding, or radical 'sensibility,' the coalition could not have survived without disintegrating into factionalism. 19

Syntheses of Wobbly conflicts have failed to examine them as the product of a cultural conflict between two differing 'sensibilities,' radical and Progressive. Significantly, scholars who admire the Wobblies and deplore their opponents often ignore the simple truth that the union's core constituency, migrant labor, was unwanted in well-established western cities. These workers were considered a constant nuisance, and feared as unruly and alien. Migrants were viewed by many urban residents as a corrupt and potentially violent presence in the city, and most importantly, one that had no real attachment to the community. Yet, they were not 'criminalized' by the implausible 'municipal government-regional industry' conspiracy suggested by Hoffman and Webb. These authors claimed that "the enforcement of vagrancy laws served to protect the interests of powerful social classes and institutions." In similar fashion, Francis Piven and Richard Cloward have suggested that municipal action

19Salvatore Salerno, Red November, Black November: Culture and Community in the Industrial Workers of the World (Albany: SUNY Press, 1989) 147, 149. 
toward the poor was intended to "influence unemployed persons to offer themselves to any employer on any terms." These assertions imply that public opinion in a city was meaningless. Supposedly, the police were henchmen of businessmen and politicians, who worked closely together to uphold a classbased power structure with which they all explicitly agreed. While the public stared blindly at the poverty and strife around them, a 'ruling class' alone determined how unemployed migrants were to be treated. 20

This synthesis is obviously flawed. During the economic crisis of 1913-14, some of the unemployed of Portland and Seattle were organized by the IWW and mounted dramatic disturbances to have their claims recognized. Instead of systemic repression, police reaction may have been representative of a community consensus that viewed the IWW unemployed as foreigners to their city, seeking a handout and representing a dangerous and unpredictable element. Predictably, Hoffman and Webb's Marxist thesis ignored the local population, and the extent of its shared values. Instead, these scholars focused on Portland and Seattle as microcosms of a larger two-class systemic struggle. More plausibly, John Townsend's explication of responses to Wobbly agitation suggested that the struggles that set Wobblies against municipal authorities were indeed systemic, but represented a battle between two increasingly marginal groups fighting cultural irrelevance more than each other. 21

Townsend's thesis inevitably raises the question of why two increasingly

20Townsend, 202-203; Dernis E. Hoffman and Vincent J. Webb, "Police Response to Labor Radicalism in Portland and Seattle, 1913-19," Oregon Historical Quarterly 87 (Winter 1986) 356-357, 365, 356.

21Hoffman and Webb, 345, 348-349; Townsend, 203-206. 
marginal groups struggled openly and bitterly against each other, while often tolerating the very economic forces that were marginalizing them. The Wobblies were not, as Hoffman and Webb would claim, a legitimate threat to industrial capitalism and American republicanism. Townsend uncovered the cultural roots of anti-IWW anger, asserting that the Wobblies rhetorically attacked both psychic and social stability among the urban middle-classes. During a time of great economic upheaval for small business, Wobblies attacked the work ethic and its psychological value in American middle-class mythology as the source of property ownership, which in turn brought the individual social respectability and provincial power. These assualts approximated taunts that which suggested the emerging reality formed by rising corporate hegemony. But corporations were distant and intangible, and also paid lip service to traditional American cultural values. Thus, Wobblies were a present and antagonistic outlet for the systemically inspired anger of local Progressives. 22

Townsend's analysis reveals the weakness of too great an emphasis on economic factors and the arbitrary separation of working and middle-class cultural values. Although the AFL was empowering some workers, Progressivism in Portland was a vehicle for substantial segments of both the middle and working-class to reign in corporate transformation of the economy. Laborers used the same language as businessmen to reject the IWW. Consequently, the importance of rhetoric in understanding the inter-class nature of anti-Wobbly activity cannot be underestimated. Referring to 
Wobblies as "alien invaders," these individuals believed themselves to be protectors of their cities. Perhaps, as Townsend suggested, this was the expression of a growing fear that small business was no longer empowered to pursue economic and cultural life in its own way. For although the IWW were not in danger of overthrowing municipal authority and capturing private property, its rhetoric expressed the hope of doing just that and was an open insult to the cultural values and longing for order of individuals who were being marginalized by the development of a sophisticated national economy. 23

Townsend could have extended his thesis to include mainstream labor as well. Robert Johnston has suggested that the recent conception of a white-collar middle class was not the predominant notion in the early twentieth century. He has pointed to a contemporary notion of "the middle class as an inclusive and egalitarian group of small producers" as opposed to their more recently viewed historiographical place "in the 'middle' between capital and labor." This idea has strong logical appeal, for in 1910, only 7\% of Portland's work force could be designated as professional, "a rough proxy" for the supposedly burgeoning white-collar middle-class. Clearly, ideas of class identity were in flux during this period of rapid economic growth and social change. Herbert Gutman pointed out in his research on late nineteenth century Paterson, New Jersey that "because a grocer owned his business and a mayor presided over a bank, it does not mean they sympathized with the social policies of a large factory owner." Thus, the concept of cultural conflict must be added to that of middleclass economic anxiety to fully explain the virtual unanimity of entire

23Townsend, 194. 
communities in opposition to the cultural paradigm of the IWW.24

Townsend's description of the typical process of anti-IWW coalition forming supports this notion. By dehumanizing Wobblies through drastic language, the 'respectable element' of the local citizenry encouraged each other to actually treat Wobblies as less than human. However, this 'element' was not a social or economic elite. It included all individuals who shared much of a set of values sometimes designated in contemporary language as 'Americanism.' Townsend conceded that "in order to act against the IWW, it was necessary to involve as many people in a town as possible," and "the press was the agency most responsible for provoking the public attitude toward Wobblies." The Coos County deportations during the summer of 1913 provide an example of the anger of an entire community aroused by lengthy press campaigns threatening Wobbly unrest. The expression of shared values, to which it was asserted that the IWW was in firm opposition, roused the citizenry to repel the "savage invaders." Unable to respond to press attacks in kind, the IWW usually became, in the words of Ralph Chaplin, "intolerably explosive. We wanted to shout labor's sufferings from the housetops." Inevitably, where the IWW was able to muster supporters, the violent confrontations known as 'free speech fights' would ensue.25

Joseph Conlin claimed that the Wobblies were "vividly aware of the value of public opinion" and often tried to communicate peacefully with the public. Yet, their open rejection of 'Americanism' was in itself hostile and

24Johnston, 33, 77-78, 122.

25Townsend, 194-196; William G. Robbins, Hard Times in Paradise: Coos Bay, Oregon, 1850-1986 (Seattle: University of Washington Press, 1988) 141-142; Townsend, 197. 
would obviously preclude constructive communication. The IWW demanded that individuals abandon the national cultural paradigm and adopt a completely new one. Only this conversion process could make their rhetoric constructively communicative. The Wobblies were perceived to be a social movement, not the misrepresented conventional union that Conlin portrays. Aileen Kraditor asserted that "in a period of great uncertainty in industrial relations" people who heard a radical labor leader utter violent words thought that their followers might well act on them. But it was not real fear of revolution, and certainly not of trade unionism, that caused frequent instances of anti-Wobbly violence. Local authorities or vigilantes viewed their own aggressive actions as preemptive of Wobbly violence. Surely, IWW rhetoric led many to believe that they were indeed a violent organization. The Progressive fear of disorder led not so much to the suppression of radical doctrines (the Wobblies retained mailing privileges), but of individuals who associated themselves personally with violent rhetoric. Kraditor found that "those who called for repression of socialists did so out of fear of 'anarchist' violence and not out of a desire to suppress radical propaganda per se." Thus, although Conlin asserted that anti-Wobbly violence was an attack on unionism, it was actually something quite different. The AFL survived because it eschewed violence, cooperated with authority, and actively combatted radicalism. Its acceptance of the framework of capitalism made its desire for peaceful reform societally acceptable. Kraditor asserted that "'violent' and 'anarchist' were labels guaranteed to ostracize any person or group wearing them." The actions of the IWW mattered little once they brought these descriptors upon themselves 
by using anti-social rhetoric. 26

The threat of the IWW was, as Townsend asserted, both psychic and social. Wobblies openly denigrated values upon which the identities of those they sought to antagonize were founded. These values were simultaneously being attacked, in a much more substantial fashion, by the growth of a national corporate economy. The sense of upheaval experienced by the opponents of the Wobblies often led to some degree of sympathy for the Progressive movement, which sought to restore a feeling of order to its constituency. The IWW openly flouted the goals of this movement rhetorically, and with physical disturbances wherever it was active. They were actively opposed not as a viable challenge to industrial capitalism, but as an organization hostile to the cultural understanding between western Progressives which served as a framework for negotiation to prevent the dominance of corporate power. 27

26Aileen S. Kraditor, The Radical Persuasion, 1890-1917: Aspects of the Intellectual History and Historiography of Three American Radical Organizations (Baton Rouge: Louisiana State University Press, 1981) 96-102.

27Townsend, 10, 14-15. 
Bibliography 


\section{Primary Sources}

\section{Archives}

Oregon Historical Society - Portland, Oregon:

Tom Burns Papers

'Mayors - Portland' and 'Oswald West' Vertical Files

Stanley Parr Archives and Records Center - Portland, Oregon:

Council Proceedings

Investigative Record Books

Mayor's Subject Correspondence

Report of the Portland Vice Commission

\section{Newspapers}

Daily News

Morning Oregonian

Oregon Journal

Portland Labor Press

\section{Books and Reports}

Addams, Jane, A New Conscience and an Ancient Evil (New York: Macmillan, 1912)

Brandeis, Louis D. and Goldmark, Josephine, Women in Industry (New York: Arno Press, 1969) 
Brissenden, Paul F., The I.W.W.: A Study of American Syndicalism (New York: Russell \& Russell, 1957)

Brooks, John Graham, American Syndicalism: The I.W.W. (New York: Macmillan, 1913)

Census of Manufactures, 1914 (Washington: Government Printing Office, 1919)

Congressional Record, 63rd Congress, 1st Session (1913)

Goldman, Emma, Anarchism and Other Essays (New York: Mother Earth Publishing Association, 1910)

Historical Statistics of the United States, Colonial Times to 1970 (Washington: U.S. Bureau of the Census, 1975)

Morris, Victor P., Oregon's Experience with Minimum Wage Legislation (New York: AMS Press, 1968)

O'Hara, Edwin V., A Living Wage by Legislation: The Oregon Experience (Salem, OR: State Printing Department, 1916)

Parker, Carleton H., The Casual Laborer and Other Essays (New York: Harcourt, Brace, and Howe, 1920)

Steffens, Lincoln, The Shame of the Cities (New York: Sagamore Press, 1957)

Women in the Fruit-Growing and Canning Industries in the State of Washington: A Study of Hours, Wages and Conditions (Washington: Government Printing Office, 1926) reprinted in McCurry, Dan C., Cannery Captives: Women Workers in the Produce Processing Industry (New York: Arno Press, 1975) 


\section{Secondary Sources}

\section{Books and Articles}

Blankenship, Warren Marion, "Progressives and the Progressive Party in Oregon, 1906-1916," Ph.D. dissertation, University of Oregon, 1966

Boyer, Paul, Urban Masses and Moral Order in America, 1820-1920 (Cambridge: Harvard University Press, 1978)

Cameron, Ardis, Radicals of the Worst Sort: Laboring Women in Lawrence, Massachusetts, 1860-1912 (Urbana: University of Dlinois Press, 1993)

Conlin, Joseph Robert, Bread and Roses Too: Studies of the Wobblies (Westport, CT: Greenwood Publishing, 1969)

Daniel, Cletus E., "In Defense of the Wheatland Wobblies: A Critical Analysis of the IWW in California" Labor History 19 (Fall 1978): 485-509

DiGirolamo, Vincent, "The Women of Wheatland: Female Consciousness and the 1913 Wheatland Hop Strike" Labor History 34 (Spring 1993): 236-255

Dubofsky, Melvyn, We Shall Be All: A History of the Industrial Workers of the World (Urbana: University of Dlinois Press, 1988)

Foner, Philip S., History of the Labor Movement in the United States, Volume III: The Policies and Practices of the American Federation of Labor, 19001909 (New York: International Publishers, 1964)

History of the Labor Movement in the United States, Volume IV: The Industrial Workers of the World, 1905-1917 (New York: International Publishers, 1965) 
Grittner, Frederick K., White Slavery: Myth, Ideology, and American Law (New York: Garland Publishing, 1990)

Haber, Samuel, Efficiency and Uplift: Scientific Management in the Progressive Era, 1890-1920 (Chicago: University of Chicago Press, 1964)

Higham, John, Send These to Me: Immigrants in Urban America (Baltimore: Johns Hopkins University Press, 1984)

Hoffman, Dennis E. and Webb, Vincent J., "Police Response to Labor Radicalism in Portland and Seattle" Oregon Historical Quarterly 87 (Winter 1986): 341-366

Hofstadter, Richard, The Age of Reform: From Bryan to F.D.R. (New York: Vintage Books, 1955) The American Political Tradition (New York: Alfred A. Knopf, 1973)

Holbrook, Stewart, "Some Notes on an Old School Radical" The Call Number 20 (Fall 1958): 4-7

Hopkins, Charles Howard, The Rise of the Social Gospel in American Protestantism, 1865-1915 (New Haven: Yale University Press, 1940)

Janik, Stephen T., "Prosperity and the Pursuit of Order: Portland, Oregon during the Progressive Era, 1900-1913," B.A. (Hon.) thesis, Harvard College, 1969

Johnston, Robert Douglas, "Middle-Class Political Ideology in a Corporate Society: The Persistence of Small-Propertied Radicalism in Portland, Oregon, 1883-1926," Ph.D. dissertation, Rutgers University, 1993 
Kessler-Harris, Alice, Out to Work: A History of Wage-Earning Women in the United States (New York: Oxford University Press, 1982) A Woman's Wage: Historical Meanings and Social Consequences (Lexington: The University Press of Kentucky, 1990)

Kornbluh, Joyce L., ed., Rebel Voices: An I.W.W. Anthology (Ann Arbor: University of Michigan Press, 1964)

Kraditor, Aileen S., The Radical Persuasion, 1890-1917: Aspects of the Intellectual History and Historiography of Three American Radical Organizations (Baton Rouge: Louisiana State University Press, 1981)

Krieger, Nancy, "Queen of the Bolsheviks: The Hidden History of Dr. Marie Equi" Radical America 17.5 (1983): 55-73

MacColl, E. Kimbark, The Shaping of a City: Business and Politics in Portland, Oregon, 1885 to 1915 (Portland, OR: Georgian Press, 1976)

Merchants, Money and Power: The Portland Establishment, 1843-1913 (Portland, OR: Georgian Press, 1988)

McKelvey, Blake, The Urbanization of America, 1860-1915 (New Brunswick, NJ: Rutgers University Press, 1963)

Merriam, Paul G., "The 'Other Portland': A Statistical Note on the Foreign-Born, 1860-1910" Oregon Historical Quarterly 80 (Fall 1979): 258-268

Montgomery, David, The Fall of the House of Labor: The Workplace, the State, and American Labor Activism, 1865-1925 (Paris: Cambridge University Press, 1987) 
Mott, Frank Luther, American Journalism, a History: 1690-1960 (New York: Macmillan, 1962)

Myers, Gloria E., A Municipal Mother: Portland's Lola Greene Baldwin, America's First Policewoman (Corvallis: Oregon State University Press, 1995)

Noble, David W., The Progressive Mind, 1890-1917 (Minneapolis: Alpha Editions, 1981)

Robbins, William G., Hard Times in Paradise: Coos Bay, Oregon, 1850-1986 (Seattle: University of Washington Press, 1988)

Rodgers, Daniel T., "In Search of Progressivism" Reviews in American History 10 (December 1982): 113-132

Rosen, Ruth, The Lost Sisterhood: Prostitution in America, 1900-1918 (Baltimore: Johns Hopkins University Press, 1982)

Schofield, Ann, "Rebel Girls and Union Maids: The Woman Question in the Journals of the AFL and IWW, 1905-1920" Feminist Studies 9 (Summer 1983): $335-358$

Salerno, Salvatore, Red November, Black November: Culture and Community in the Industrial Workers of the World (Albany: SUNY Press, 1989)

Toll, William, "Ethnicity and Stability: The Italians and Jews of South Portland, 1900-1940" Pacific Historical Review 54 (May 1985): 161-189

Townsend, John Clendenin, Running the Gauntlet: Cultural Sources of Violence Against the I.W.W. (New York: Garland Publishing, 1986) 
Trachtenberg, Alan, The Incorporation of America: Culture \& Society in the Gilded Age (New York: Hill and Wang, 1982)

Tyler, Robert L., Rebels of the Woods: The I.W.W. in the Pacific Northwest (Eugene: University of Oregon Press, 1967)

Wiebe, Robert H., The Search for Order, 1877-1920 (New York: Hill and Wang, 1967) 